\title{
EENIGE VERHALEN IN TALEN, GESPROKEN OP SUMBAWA, TIMOR EN OMLIGGENDE EILANDEN. \\ DOOR
}

Mr. Dr. J. C. G. JONKER.

Naar aanleiding van de, door Dr. G. A. J. Hazeu besproken Javaansche verhalen in het Album aangeboden door het Bataviaasch Genootschap van Kunsten en Wetenschappen aan het OriëntalistenCongres te Hanoi, wordt in Deel XLVI van het Tijdschrift voor Indische Taal-, Land- en Volkenkunde, bladz. 18 vgl. door Dr. N. Adriani de inhoud van eenige verhalen in het Barée, enz. opgegeven.

Het zal wel niet onbelangrijk zijn iets mede te deelen over de verspreiding dezer verhalen, voor zooverre mij bekend, bij de bewoners der Kleine Sunda-eilanden, beoosten Lombok. Het t. a. p. pag. 119 vgl. medegedeelde verhaal van $i$ Tengo, "de domme", is ook bij de Bimaneezen bekend. De Bimaneesche lezing kan men vinden in de door mij uitgegeven Bimaneesche texten (Verh. v. h. Bat. Gen. v. K. en W. Deel XLVIII $2^{\text {de }}$ stuk, pag. 31) onder den titel: mpáma la Bango, verhaal van Bango.

Aangezien ik indertijd geen vertaling bij deze teksten gegeven heb, moge hier eene van het genoemde verhaal volgen.

Vooraf zij opgemerkt, dat bango in het Bim. (voor zooverre mij bekend) geen beteekenis heeft, (die van "reiger" komt hier natuurlijk niet te pas); doch in het Makassaarsch "gek, dwaas" beduidt. Het valt niet te ontkennen, dat, gegeven de in vele opzichten groote invloed, welken de Makassaren op de Bimaneezen hebben uitgeoefend, de naam Bango doet vermoeden, dat de Bimaneezen het verhaal aan de Makassaren ontleend hebben; hoewel 't mogelijk kan zijn, dat het woord vroeger ook in het Bim. gangbaar was, misschien nog in sommige deelen van het land in gebruik is.

\section{Vertaling.}

Er was eens, naar verhaald wordt, iemand die Bango heette. Hij sprak tot zijne moeder: "moeder, ga voor mij de dochter van gindsche vrouw ten huwelijk vragen." Zijne moeder antwoordde: "Kind, wij zijn bang om naar die lieden heen te gaan, want zij zijn rijk." 
Bango sprak: "beproef maar eens te gaan, moeder; wellicht zullen die man en vrouw medelijden met ons hebben, zoo is toch eenmaal steeds de gang van zaken tusschen man en vrouw."

Daarop ging de vrouw naar de moeder van het meisje; toen zij bij het huis gekomen was, riep de vrouw haar toe en noodigde haar uit te gaan zitten en vroeg haar: "wat toch is de tijding, waarmede gij komt?" Zij antwoordde: "ja, goede tijding, zeer vele betuigingen van eerbied van uw slaaf Bango, die mij bevolen heeft te komen om de ruimte onder het huis aan te vegen en de uitgekauwde betelpruimen op te rapen", (verbloemde wijze om de huwelijks-aanvraag uit te drukken). De man en vrouw antwoordden: "goed; al was 't ook een halve hond of een half varken, dat op mijne deur afkwam, dan zou 't nog een geluk voor mijn kind zijn, laat staan iemand als Bango." Toen werd Bango (als a. s. schoonzoon) aangenomen, waarop de vrouw naar huis terugkeerde en dèn man (den vader) en Bango mededeelde, dat de lieden medelijden hadden gehad en hem aangenomen hadden.

Zij gaf Bango (volgende) lessen: „mijn zoon, vele zijn de zeden en gedragingen (welke gevolgd moeten worden) door iemand, die een meisje vrijt. Als gij uwe (aanstaande) schoonouders ziet zitten, loop dan niet tegen hen aan; zorg dat uw kain goed zit en laat uw slendang zakken; loop niet rond het lichaam alleen bedekt met een slendang; wacht niet, bij alles wat er te doen is, totdat gij bevolen wordt; zoo ook, als gij brandhout gaat halen, snijd het dan goed gelijk af, bind het vervolgens goed bijeen en draag het dan; als gij tehuis komt, werp het dan zachtjes neer; zóó zijn de gewoonten van iemand, die om een meisje vrijt."

Bango antwoordde: "goed moeder, wees niet bezorgd".

Daarop bracht men Bango in optocht naar zijne schoonouders om daar te gaan dienen; en hij bleef aldaar.

$\mathrm{Na}$ vier of vijf dagen zeide zijn sehoonvader: "zoon, ga eens brandhout halen." Toen ging hij heen; op de bergen gekomen, . greep hij een boom, welke geheel dood was, en nam dien, den geheelen stam met takken, wortels en al op zijne schouders en droeg hem naar het huis van zijne schoonouders. Aldaar gekomen, smeet hij den boom met geweld neer, zoodat zijne schoonouders schrikten toen zij het geluid van het hout, dat Bango met een plof neerwierp, hoorden. Zijn schoonvader sprak: "dit is een vervloekte kerel! Hoe kan men een boom met takken en wortels uitgestrekt op de schouders nemen?" maar hij zeide dit bij zichzelf brommend tegen 
zijne vrouw. Bango steeg (ging) toen in huis; zijn schoonvader zette hem rijst voor; toen ging hij eten, een mandje vol rijst en een bord vol toespijs gingen op. $\mathrm{Na}$ het eten kwam er een hevige regen. Zijn schoonvader zeide: "mijn zoon, ga naar boven en herstel het dak van ons huis eens, want het lekt heel erg." Bango ging naar zolder en maakte het, overal waar het lekte, in orde. Daarna keek hij naar beneden en kreeg zijne verloofde in 't oog, die juist bezig was zich met een geneesmiddel in te wrijven, zoodat haar borst geheel zichtbaar was. Bango daalde ijlings af en ging naar zijn eigen huis en sprak tot zijne moeder: "moeder, wat zijt gij toch een ellendig oud wijf! waarom hebt ge uwe oogen niet beter opengedaan ten opzichte van dat meisje ?" Zijne moeder antwoordde : "waarom zegt gij dat?" Bango sprak: "waarom, waarom zegt ge? gij hebt uwe oogen niet opengedaan, zij is iemand met twee steenpuisten, welke naast elkander op hare borst zitten en waarvan elk zoo groot is als een kopje!"

De moeder antwoordde: "ongeluk van een Bango, aartsdommerik, dat zijn geen steenpuisten, dat heeten de borsten, zoo zijn wij vrouwen (gevormd)." Bango antwoordde: "ga zelf haar trouwen, moeder; ik heb geen zin in iemand, wier borst zoo opgezwollen is." Zijne moeder antwoordde: "laat 't zoo blijven, als gij er geen zin in hebt, ga zelf dan eene goede vrouw zoeken." Bango ontwoordde: "goed, ik zal zelf eene zoeken; maar wat voor een vrouw moet ik zoeken?" Zijne moeder zeide: "zoek eene vrouw, die stil en zacht is." Daarop ging Bango eene vrouw zoeken.

Nadat hij een poosje voortgegaan was, zag hij eene doode vrouw languit op den weg liggen. Hij dacht: "dit is "misschien eene stille en zachte vrouw, zooals mijne moeder straks gezegd heeft." Daarop nam hij haar rechtuitgestrekt op zijne schouders en droeg haar naar huis; hij ging regelrecht naar zijne kamer en legde haar daar neder en begon haar te vertellen, tegen haar te lachen en te schertsen en haar te kittelen. Toen zijne moeder lachen en schertsen in de kamer hoorde, kwam zij binnen om te kijken. Bij het zien van het menschenlijk zeide zij: "Ongeluk van een Bango, aartsstommerik, is 't behoorlijk om een menschenlijk hier te brengen? ga heen en breng deze doode terug!" Bango antwoordde: "Je eigen bek heeft mij bevolen een stil en zacht mensch te zoeken, nu er zulk eene vrouw is, beveelt ge mij haar weer terug te brengen. Wat voor iemand moet ik dan werkelijk zoeken?" Zijne moeder antwoordde: "Zoek iemand, die beleefd en vriendelijk is." 
Daarop nam Bango het lijk weer op zijne schouders en bracht het terug naar de plaats (waar hij het gevonden) had. Daarna ging hij er wederom op uit om eene beleefde en vriendelijke vrouw te zoeken; hij was nog niet ver gegaan of hij zag wederom een dood mensch met openstaanden mond en wijdgeopende oogen. Bango sprak: "Zusje, reeds lang heeft mijne moeder mij bevolen een beleefd en vriendelijk mensch te zoeken, nu eerst tref ik haar aan; kom, laat ik u op mijne schouders nemen en naar huis brengen." Wederom nam hij het lijk rechtuitgestrekt op zijn schouder en droeg het naar zijn huis; daar aangekomen, omwond hij het en bond het vast aan den middenstijl, waarna hij begon te lachen en te schertsen. Toen zijne moeder den stank rook, kwam zij binnen om te kijken en zag een menschenlijk door Bango aan den middenstijl gebonden. Zijne moeder zeide: "galgenbrok van een Bango, aartsstommerik, komt 't. te pas, dat gij hier iemand (een doode), die reeds zoo stinkt, in huis brengt? Doe haar hier vandaan en ga haar begraven!" Bango antwoordde: "dit is toch een allerellendigst oud wijf, van al wat ik doe, is er niets goed!" Daarop droeg hij dat (doode) mensch weg en begroef haar, waarna hij naar huis terugkeerde.

Toen de oude vrouw een wind liet, sprak Bango: "deze oude vrouw stinkt al." Daarop sleurde hij haar voort. "Kom, laat ik deze oude vrouw (of: u) gaan begraven; zij stinkt (of: verrot) al." De vrouw antwoordde: "Bango, galgenaas, ik ben nog niet dood!" Maar Bango sleurde haar met alle geweld voort, omdat zij stonk; toen hij op het veld kwam, bond hij haar met touw van de kalelengplant, vervolgens groef hij haar graf; toen het af was, sleepte hij de oude vrouw er in en begroef haar in het graf. Daarna keerde Bango naar huis terug waar zijn vader ook een wind liet. Bango zeide: "o heer, nu stinkt ook mijn vader, nu moet ik hem ook maar in den grond gaan stoppen."

Daarop ging hij heen en sleurde zijn vader uit alle macht mede; (deze riep): "Bango, ik ben nog niet dood; den stank van den wind, welken ik gelaten heb, hebt gij geroken." Bango sprak : "wat (zegt ge) van een wind? mijne moeder heeft gezegd, als iets stinkt, ga het dan begraven." Toen begroef hij hem.

Daarna liet Bango-zelf een wind; toen sprak hij: "O je, nu stink ik-zelf ook!" Hij groef weer aarde uit, toen het gat ongeveer (zoo) diep was (dat het hem) tot den hals (kwam), sprong hij er in en begroef zichzelf tot aan den hals.

Als het avond geworden was, kwamen twee dieven, die uit 
stelen wilden gaan, daar langs. Zij stootten tegen het hoofd van Bango. Deze sprak: "au, wie stoot daar tegen mijn hoofd?" De dieven antwoordden: "wie is dit (daar)?" Bango sprak: "ik, Bango, ik stink al, dus moest ik mij-zelf begraven." De dieven zeiden: "gij handelt heel verkeerd, om er toe te besluiten, uzelf levend te begraven. Kom, laten wij samen uit stelen gaan." Bango sprak: 't is goed, maar graaft mij eerst op en trekt mij naar boven."

Daarop groeven de dieven hem op en trokken hem naar boven, waarop zij met hun drieën uit stelen gingen. Bij het huis van iemand gekomen, spraken de dieven: "zoo (moet gij doen) Bango, gij moet beklimmen (gaan in) het huis, wij beiden zullen beneden (den boel) in ontvangst nemen." Bango zeide: "best; maar wat moet ik nemen?" De dieven zeiden: "als gij iets zwaars voelt, neem het dan."

Daarop ging Bango naar boven (in het huis) en betastte in 't rond al wat in het huis van die menschen was. Toevallig tilde hij een der steenen, waarop men een pot te koken zet, op; "dit is misschien het zware, wat zij bevolen hebben te nemen." Hij nam alle (drie de steenen) op zijn schouder en sprak: "hier, een beetje vlug, neemt aan, 't is erg zwaar, hier!"

De dieven namen ze aan; toen zij echter zagen, dat het steenen waren, wierpen zij ze weg; "waartoe Bango, brengt gij deze steenen, waarop de menschen hun pot te koken zetten, naar beneden?" Bango sprak: "gijzelven hebt bevolen iets zwaars te kiezen om te nemen; maar nu, wat moet ik nu weer nemen?" De dieven antwoordden: " ongeluk van een Bango, spreek niet zoo luid, de menschen van het huis zullen nog wakker worden; ga zien of gij iets wits, dat licht is, vindt; neem het dan en breng het naar beneden." Bango ging daarop weer aan het rondtasten, tot hij bij dat zoeken het mandje voor kapas aanraakte, dat hij optilde; nadat hij het geopend had, zag hij, dat (de inhoud) geheel wit was; hij sprak: "dit is, naar ik meen, het witte, waarover zij zooeven gesproken hebben." Hij nam het in zijn arm en bracht het. Op den weg (buiten) gekomen, zeide hij: "hier, neemt spoedig aan, hier!" De dieven namen het aan. Toen zij zagen, dat het een mandje was vol gezuiverde kapas, zeiden zij: "ongeluk van een Bango, wat hebt gij te maken met die kapas, welke door de vrouw des huizes gesponnen moet worden?" Bango sprak: "geeft 't dan juist en duidelijk te kennen, wat moet ik nu werkelijk nemen?" De dieven antwoordden : "ellendige 
domkop, neem iets glinsterend roods, als gij 't ziet." Daarop ging hij tastend rond, maar zag niets glinsterend roods; toen daalde hij af tot onder de bank bij de kookplaats. Toen hij het glimmen van het vuur, dat men ingerekend had in de kookplaats, zag, ging hij er op af, en haalde het vuur er uit, en wikkelde al de gloeiende kolen als een groot pak, in zijn kain. Daarop ging hij heen; maar het vuur verbrandde zijn kain, zoodat de kolen er uit vielen; telkens als er eene viel, zeide hij: "daar, één is er beneden"; zoo lang hij liep, sprak hij: "daar, één is er beneden." Daardoor schrikten de menschen in het huis wakker en hoorden iemand zeggen: "daar, één is er beneden"; zij riepen hem aan en vroegen: "wie is daar?" Hij antwoordde: "ik, Bango." De huisbewoners zeiden: "wat heb gij hier in mijn huis te komen bij nacht en ontijd?" Bango antwoordde: "ik ben gekomen om te stelen."

Toen zijne mede-dieven gehoord hadden, dat de huisbewoners wakker geworden waren, hadden zij de vlucht genomen, terwijl Bango in het huis van die menschen was.

De huisbewoners staken een fakkel aan en zeiden tot Bango : " wat hebt gij gestolen?" Bango antwoordde: "ten eerste zeiden mijne makkers: "tast rond of er iets zwaars is" ; waarop ik ging zoeken en toen ik het vond, ging ik heen en gaf het; zij wierpen 't weg zoodra zij het aangenomen hadden en zeiden: "wat hebt gij met de steenen van de kookplaats van noode; ga iets wits en lichts nemen"; toen ging ik weer zoeken en tilde ik toevallig iets lichts op en gaf het; zij zeiden wederom: "wat hebt gij er aan eene mand kapas van de vrouw te nemen; ga iets glinsterend roods nemen" ; ik ging weer rondtatten en ging door tot onder de kookplaats, waar ik iets glinsterend roods zag en wikkelde het allemaal in; het viel verspreid, stuk voor stuk, overal neer, zoo lang ik liep, mijn kain is daarbij ook nog bedorven."

De huisbewoners waren nict boos toen zij hoorden wat Bango vertelde; zij lachten luidkeels toen zij vernamen, hoe Bango bij het stelen was te werk gegaan. Zij zeiden: "Bango, ga niet meer uit stelen, kom met ons wonen." Bango sprak : "goed". Daarop woonden zij samen met Bango.

Toen zij bemerkten, dat Bango een eerlijk en rechtschapen karakter had, hielden zij van hem en vertrouwden hem. Eens wilden de bewoners van het huis hun veld gaan bewerken; zij zeiden tot Bango: "Bango, wij willen het veld gaan bewerken, pas op het huis en voorts, zorg goed voor uw broertje Keu, (algemeene naam voor kleine 
jongens); als het tijd voor het bad zal zijn, baad hem dan, maar baad hem niet met koud water, maak het water een weinig warm." Bango sprak: "'t is goed." Daarop vertrokken allen naar het veld.

Toen de tijd voor het bad gekomen was, warmde hij het water tot het goed kookte; toen goot hij het uit in den pot, waarin Keu gewoonlijk gebaad werd; hij ging Keu halen en baadde hem en dompelde hem geheel en al in het kokende water in den pot. Daarvan stierf het kind, zijn vel was geheel los gegaan; nog twee- driemaal dompelde hij het kind in den pot; daarna nam hij een sarong en wikkelde het kind daarin en maakte alles in orde en legde het weer in zijne wieg.

Daarop kwamen de ouders van Keu terug en vroegen: "Bango, hebt gij zooeven uw broertje gebaad?" Bango sprak: "ik heb hem gebaad met warm water waarop hij straks lekker is gaan slapen, tot nu toe is hij volstrekt nog niet wakker geworden." De moeder ging naar haar kind kijken, daar zij hem wilde zoogen. Toen bemerkte zij; dat haar kind geheel en al wit was, terwijl het vel overal was gebarsten en gescheurd en dat hij dood was. De ouders begonnen daarop te weenen, te schreeuwen en te jammeren, omdat zij zagen, dat hun kind dood was. Zij sloegen en ranselden op Bango en joegen hem weg en lieten hem niet meer in huis wonen. Bango snelde naar beneden (het huis uit) en maakte zich uit de voeten. Zij begroeven het kind, met de bijbehoorende plechtigheden.

EINDE.

Hetzelfde verhaal is mij, met eenige afwijkingen, ook bekend in het Kupangsch, de taal vroeger gesproken in een groot deel van Zuid-Westelijk Timor, thans met enkele uitzonderingen beperkt tot het eiland Samau. Aangezien er nog nimmer eene proeve van die tal gegeven is en ik ook in den eersten tijd geen gelegenheid zal hebben om uitvoeriger mededeelingen te doen, geef ik hier den tekst met vertaling en interlineaire vertaling.

Het Kupangsch vertoont de meeste verwantschap eensdeels met het Rotineesch en Timoreesch, anderdeels met het Tettumsch, enz., doch verschilt van genoemde talen in sommige opzichten aanmerkelijk.

Omtrent de uitspraak heb ik alleen op te merken, dat de $e$ en $o$ aan het eind van een woord steeds (gelijk ook als regel in het Rotineesch) als ̀̀ en ò klinken.

Een klinker tusschen haakjes, achter een woord in den tekst gevoegd, 
duidt den volledigen vorm van het woord, als afzonderlijk woord of in de pauze, aan; na woorden, waarin omzetting van de slotlettergreep heeft plaats gehad, staat de ware vorm tusschen haakjes. Een consonant tusschen haakjes voor een woord duidt aan, dat deze daar door anderen pleegt uitgesproken te worden.

In de interlineaire vertaling heb ik die verbale woorden, welke zich niet met de verkorte pers. vnw. verbinden, door den infinitief weergegeven; in het andere geval zijn zij vervoegd. Hierbij is op te merken, dat in den tekst van dit verhaal, gelijk de gewoonte is van sommige Kupangers op een gedeelte van het eiland Samau, dikmaals de vorm voor den derden persoon enkelvoud en meervoud ook in de overige personen gebezigd wordt; de andere vorm is er dan tusschen haakjes achtergevoegd; bijv. Ku neta, (ku meta), welke dan respectievelijk met: gij zien (gij, gij-ziet), worden weergegeven.

Van grammaticale opmerkingen en vergelijkingen zal ik mij onthouden voor zooverre zij niet bepaald noodzakelijk zijn voor het verstaan.

Enkele telkens voorkomende woorden, welke in het Hollandsch te veel plaats zouden innemen, zijn in de aanteekeningen verklaard.

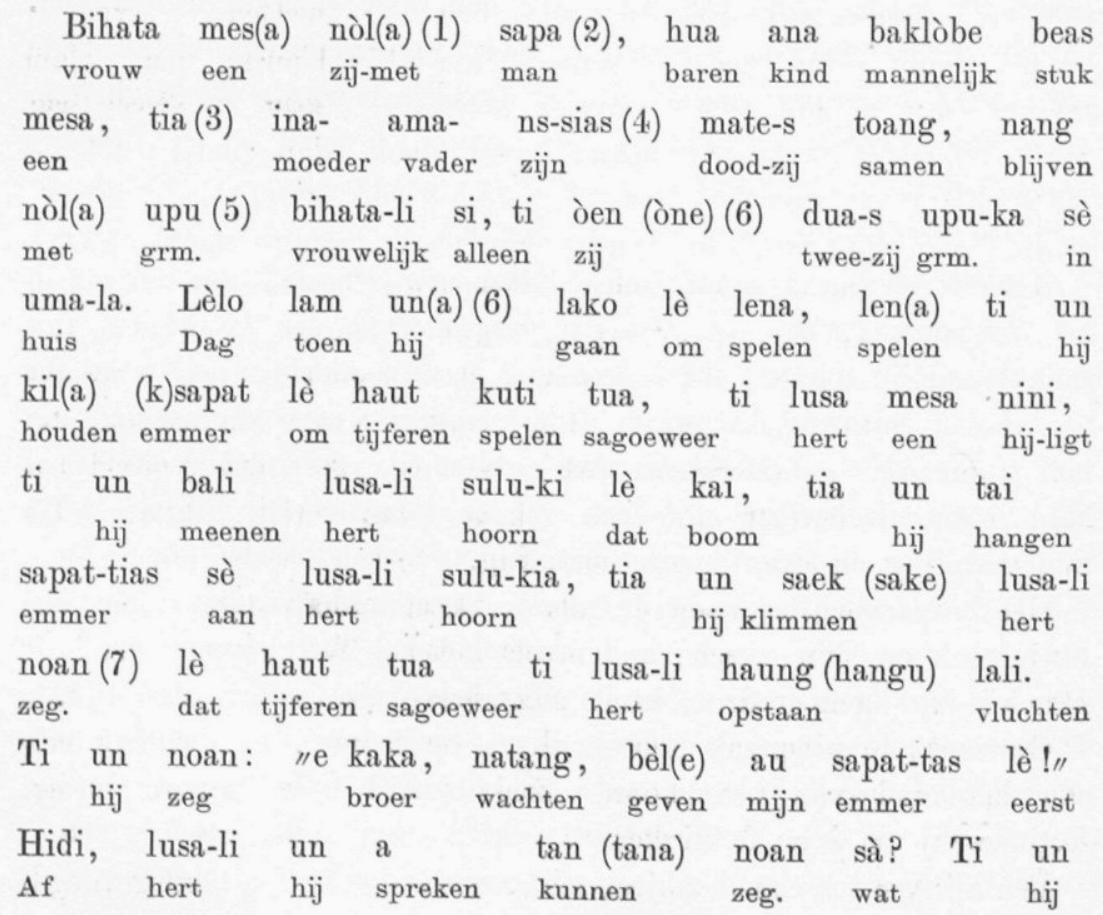


lail (lali) lako alas-su dale. Ti lako, ti tek (teka) upu-kia, vluchten gaan bosch binnen gaan melden grm. noan: "upu, auk laok (lako) (8) tai au sapat-tias sè zeg. grm. ik gaan hangen mijn emmer an kai mesa, tia au lè saek (sake) haut tua, ti un boom een ik willen klimmen tijferen sagoeweer hij haung (hangu) lali, $\operatorname{nin}(\mathrm{i})$ au sapatı. Upu-ki noan : opstaan vluchten hij-draagt mijn emmer Grm. zeg. "mla lusa, eta $\mathrm{ku}$ neta (of:meta) $-\mathrm{s}$, kil(a) (k)hela lè dat hert als gij zien (gij-ziet)-ze houden hakmes om dati- s, ta mla lusa, ta in-ka, (9) sisi." Tia: "ola dooden-ze want dat hert want eten vleesch morgen lè, upu, au kil(a) hela, lè au ket(a) lusa lam aukeerst grm. ik houden hakmes om ik ik-zie hert dan ikdati- $\mathrm{n} \prime$. Tia ola kam un kil(a) hela mesa, lè laok dooden-hem morgen toen hij houden hakmes een om gaan nuting lusa-lia, ti laok ti net(a) lusa lò, net(a) tana-anahij-zoekt hert gaan hij-ziet hert niet hij-ziet "kind ngias keng apa, ti nu laok ti dait (dati) tèle tana-ana vechten elkander hij gaan slaan dooden kind mesa, ti hal(a) nòla-n lako un uma. Ti tek (teka) upu-ki, een dragen met hem gaan zijn huis melden grm.

noan: "upu, $\mathrm{ku}$ ma tinang lusa-li!" Upu-ki ma lam zeg. grm. gij komen zien hert grm. komen en atuli. Upu-ki ngau noan:" ku laok dait (dati) tèle mensch Grm. brommen zeg. gij gaan slaan dooden atuli ana lè tao sà, mèt Kompnia ming ngam mèt mensch kind om doen wat zullen Compagnie hooren dan zullen sakeng (10) sòleng ku." "Upu, auk lako-ng, d̀n keng doen-bestijgen werpen u Grm. ik gaan-ik zij vechten apa, ta auk dati- n". "Eta keng apa lam seda- s, elk. dus ik dooden-hem. Als vechten elk. dan scheiden-ze bòel (bòle) in-dati-(9) lò, lò kam tao tèle kita. "Tia kunnen dooden niet, niet dan maken dooden ons

tana-ki baklòbe-li noan:" ola kam auk lako lam au kind mannelijk zeg. morgen dan ik gaan dan ik keta-s lè keng apa kam auk seda- sı. Ti ola kam ik-zie-ze dat vechten elk. dan ik scheiden-ze morgen toen un lako, lako ti nahtòm masan dua sè pukun mesa, hij gaan gaan hij-ontmoet tijger twee in bosch een 
òen keng apa, ti un laok tama sè tlala lè seda- $\mathrm{s}$, zij vechten elk. hij gaan ingaan in midden om scheiden-ze seda. mò òen pisu- $\mathrm{n}$ ti mòes-(m)nès. Ti un noan:" mi(a) sch. nu zij scheure-n vol wonden hij zeg. gijl. pius (pisu) au dèken, ta au upu-ng tek(a) au, lè scheuren mij djangan, want mijn grm.-mijn zeggen mij dat mi(a) keng apa, kam auk sed(a) mia." Mò masan, òen gijl. vechten elk. dan ik scheiden u-l. $\mathrm{Nu}$ tijger zij $\tan (\mathrm{a})$ in-á-(9) ki elola, ta un seda, mò òen pisu- $\mathrm{n}$ kunnen spreken hoe dus hij scheiden nu zij scheuren-hem ti un bòel (bòle) lò sòn, ti haung (hangu) lali. Ti ma hij kunnen niet meer opstaan vluchten komen upu-ki, apa- ka bau papa sisí Ti upu-ki noan: "mò grm. lichaam geheel wond enkel grm. zeg. nu satao-n lè $\mathrm{ku}$ apa- $\mathrm{m}$ papa- isi-kia?" "Upu-ng teka, waarom dat uw lichaam-uw gewond-zeer Grm. mijn melden noan:" eta laok nahtòm (of: mahtòm) atuli kèng apa zeg. als gaan ontmoeten ( gij-ontmoet) mensch vechten elk, ellàm laok seda. Tia auk laok nahtòm (of: kahtòm) dan gaan scheiden ik gaan ontmoeten (ik-ontmoet) atuli tène at(11) dua, lapa el uma-li siu-ki niung (12) mensch groot twee hoog als huis goot neerlaten (h)ngulu-n blalatas (13) tukun, tia òen pius (pisu) apa, ti nagel -hun lang slechts zij scheuren elk. auk laok sè tlala lè seda- $s$, tia òen pius (pisu) au ik gaan in midden om scheiden-ze zij scheuren mij baba". Upu-ki noan: "bòel (bòle) lò, laok meta- s, ellàm ook Grm. zeg. kunnen niet gaan gij-ziet-ze dan lali, ta masan, atuil (atuli) lò, $\mathrm{ku}$ meta- $\mathrm{s}$ sè èpe vluchten want tijger mensch niet gij gij-ziet-ze in veld tam pukun, ellàm lali ta masan, ta mèt pius (pisu) of bosch dan vluchten want tijger want zullen scheuren tèle $\mathrm{ku}$ "Ti upu-ki nanas nian, lè dos(a) papa- lias. dooden u grm. warmen klapper om pappen wond

Tia un noan upu-ki, noan: "upu, eta au papa-lias banan, hij zeg. grm. zeg. grm. als mijn wond goed eta auk laok lena lè au nahtòm (of: kahtòm) keng als ik gaan spelen dat ik ontmoeten (ik-ontmoet) vechten apa-ka mò auk lali- ng." Tia upu-ki noan: "hao, elk. dan ik vluchten-ik grm. zeg. ja 
lail (lali) lò kam òen tao tèle ku." Ti papa-lias banan, vluchten niet dan zij maken dooden u wond goed ti un laok lena, len(a) ti kuhit uma dèhe," tia hij gaan spelen spelen voorbijgaan huis eenige atuli-lias haman, noan: "tana hmoa, ma lè ka ngae!" mensch roepen zeg. kind wees komen om eten mais Ti un lali, lali ti ma tek(a) upu-kia, noan: "upu, hij vluchten vl. komen melden grm. zeg. grm. auk laok kuhit uma dèhe tia òen haman au, noan: ik gaan voorbij huis eenige zij roepen mij zeg. "tana hmoa, ma lè ka ngae, ti auk lali- ng ma kind wees komen om eten mais ik vluchten-ik komen mlia." Ti upu-ki noan: "haman $\mathrm{ku}$ lè laok ka ngae dit grm. zeg. roepen u om gaan eten mais ellá lam ku laok lè ka, ta kit(a) sà- sà (14) nena." zoo dan gij gaan om eten want ons wat-wat eigendom Tia: "ola lè upu, au kil(a) au (k)hale-ki, laok lè morgen eerst grm. ik houden mijn klapperdop gaan om kodan ngae, ma lè kit(a) dua- $\mathrm{t}$ ka." $\mathrm{Ti}$ ola kam ik-vraag mais komen om wij twee-wij eten morgen toen un lako, kil(a) hale mesa, laok kula uma-lias un hij gaan houden dop een gaan mis huis hij nahtóm bihata mes(a) hè kukis, tia un noan. bihatahij-ontmoet vrouw een verkoopen koekjes hij zeg. vrouw ngi: "ku bèl(e) au ngae tia sè au hale-kia!" Bihata-ngi gij geven mij mais eens in mijn dop Vrouw noan: "auk bèl(e) ku sà, au kil(a) ngae nè-i lò." "Mò zeg. ik geven $\mathrm{u}$ wat $i \mathrm{k}$ houden mais hier niet En slahin ku haman lè bèl(e) ngae lè sà? $\mathrm{Au}$ upu-ng tadu gisteren gij roepen om geven mais om wat Mijn grm-mijn bevelen kil(a) hale ma lè bèl(e) ngae." Bitata-ngi dai bèl(e) houden dop komen om geven mais Vrouw willen geven lò, tia un papas nin(i) lea-n bihata-ngia, ti kat(a) batu, niet hij slaan zij-ligt valt-zij vrouw tillen steen ti tutu hòen bò- $n-$ nia, ti un kat(a) kukis-sias, ti kloppen stuk hoofd haar hij tillen koekjes

$\mathrm{ka}$, ka hidi, ti hal(a) bihata-ngi laok un uma, ti un eten eten af dragen vrouw gaan zijn huis hij nène bihata-ngi sè un mana, buni upu-kia. Nal(a) hij-legt vrouw op zijne plaats verbergen grm. Het-bereikt 
(k)dèdeng dua, bihata-ngi buin, ti lael(15)-penga-lias hòle- $\mathrm{n}$ etmaal twee vrouw rieken vleeschvlieg kakken-haar sinun sisí, ti un a sinun-nias, noan: "au sapa-ng-ngi maden enkel hij spreken maden zeg. mijn vrouw-mijn un hu- nian ni elòl(a)-lè? Apa- ki nian- òn haar smeren klapper hoe toch Lichaam klapper-uitpersel sisí!" Tia a mò si nuli sinun-nias, mò bihataenkel spreken nu vegen hij-doet-opzijn made nu vrouw ngi buin hòso sòn. Ti upu-ki noan : "e, mò sà rieken stinken reeds grm. zeg. hé nu wat buin hòso isi-kia?" Tana-kia noan: "auk tan(a) lò". Tia ruiken stinken zeer Kind zeg. ik weten niet upu-ki doha- $\mathrm{n}$ lè laok likun, un laok tinang tana-ki grm. bewaken-hem dat gaan buiten zij gaan kijken kind mana-lu, sà buin isi-kia, laok tinang tia-mò bihata-ngi plaats wat rieken zeer gaan kijken toen vrouw mate lè hus sòn. Tia upu-ki noan: ku laok tao dood dat opgezwollen reeds grm. zeg. gij gaan maken tèle bihata-ngi mla lè tao sa?" "Au kodan ngae, lam dood vrouw die om doen wat $\mathrm{Ik}$ ik-vraag mais toen un bél(e) au lò, ta auk papas ti lea, ti au kat(a) zij geven mij niet dus $i k$ slaan vallen $i k$ tillen batu ti tutu, ti auk hal(a) kòla- $\mathrm{n}$ ma mla lè steen kloppen ik dragen ik-met-haar komen dat om tao au sapa-ng." "Lè ku sapa(a) nitu-lè? Mate lè maken mijn vrouw-mijn Dat gij trouwen lijk dan Dood dat bui(n) hohòso sòn mlan! Lalaba laok kat(a) suan, lè rieken stinken reeds immers Snel gaan tillen schop om laok puan! Ti un kat(a) suan-nia. Upu-ki noan: "laok gaan begraven hij tillen schop Grm. zeg. gaan kail (kali) bòlo lè ma lè nikit (of: mikit) lè laok graven kuil om komen om tillen ( gij-tilt) om gaan puan!" Ti laok, kail (kali) hidi bòlo, un ma. Ma begraven gaan graven af kuil hij komen Komen ti upu-ki noan: "lulu sè (k)nèhe-ka lè laok puan, lò grm. zeg. rollen in mat om gaan begraven niet kam kuimdòn ming ngam kit(a) dapat sala." Ti un lulu dan resident hooren dan wij (Maleisch) hij rollen sè nèhe-kia, ti laok puan. Puan ti palit ma, ma in mat gaan begraven Begr. terug komen, $\mathrm{k}$. 
nal(a) (k)dèdeng mesa tam lé dua, lam òen dua-s het-bereikt etmaal een of tot twee toen zij twee-zij upu-ki dad(a) buan, ti upu-ki nisu. Ti un a, noan : grm. zitten samen grm. zij-veest hij spreken zeg. "ku mate sòn, upu, ku buin sòn mlia." Ti upu-ki gij dood reeds grm. gij rieken reeds dit grm. noan: "auk mate-ng bi." "Lo ku buin sòn." Upu-ki zeg. ik dood-ik nog (niet) Neen gij rieken reeds Grm. noan: "auk nisu- ng (of: kisu-ng), mò auk mate-ng lò." zeg ik veesten-ik ( ik-veest-ik) mar ik dood-ik niet Ti un hi lò mò kat(a) suan, laok kali bòlo nè hịj luisteren niet maar tillen schop gaạn graven kuil aan bihata-ng un in-laok-puan-(9) ni (k)halin-nia, laok kail (kali) vrouw hij gaan-begraven zijde gaan graven hidi bòlo ti ma. Ma ti pel(a) noan: "ma lè takom, (16) af kuil komen Komen trekken zeg. komen dat gaan

au kail (kali) hidi, ku bòlo sòn." Tia upu-ki noan : ik graven af gij kuil-hebben reeds grm. zeg. " auk mate-ng bi auk nisu- ng, ta buin- nà. "Un ik dood-ik nog (niet) ik veesten-ik dus rieken dus Hij noan: "lò, $\mathrm{ku}$ buin el au sapa-ng-nga kon. Blalan-ni zeg. neen gij rieken als mijn vrouw-mijn ook Oude

dai laok lò mò un $\operatorname{pel}(\mathrm{a})$ kos blalan-ni, piul (pilu) willen gaan niet maar hij trekken sleepen oude werpen laok sè bòlo-kia dale, ti kat(a) batu, ti tenan, kui gaan in kuil binnen tillen steen opleggen vegen (k)dale-ki lako sè bòlo-ka. Blalan-ni daek (dake) in-nahan (9). aarde gaan in kuil Oude steeds schreeuwen tun nè bòlo-ki, mò un kui (k)dale laok sè bòle-ki, maar in kuil maar hij vegen aarde gaan in kuil inu bòlo-ki sòn, ti blalan-ni huhukun, ti mate. Mate ti vol kuil reeds oude spartelen dood Dood un haung (hangu) ma lako uma, si dad(a) sè uma-lia hij opstaan komen gaan huis alleen zitten in huis lè langan-langan, ti un a, noan: "au sapa- ng- ò om suffen hij spreken zeg. mijn vrouw-mijn-ook mate, au upu-ng ò mate, ti auk si- ng langan-langan dood mijn grm.-mijn-ook dood ik alleen-ik suffen lòlen nè um(a) mlia." Ti un dadàd(a) (k)dèdeng mesá ook in huis dit hị zitten etmaal en 
tam lè dua, lam un nisu, nisu ti un noan: "auk of tot twee toen hij hij-veest hij-v. hij zeg. ik buin sòn, auk mate-ng sòn, au buin- ni èl au upu-ng rieken reeds ik dood-ik reeds mijn rieken als mijn grm.-mijn nòl(a) au sapa- ng kòn mlia!" Ti un kat(a) suan, lako met mijn vrouw-mijn ook dit hij tillen sehop, gaan ti kali bòlo sè upu-ki (k)halin-nia, kali hidi, ti un graven kuil aan grm. zijde graven af hij tama ti ni-ni sè bòlo-ki dale, si lè bua bèle- $\mathrm{n}$ ingaan hij-ligt in kuil binnen wie om indoen geven-hem (k)dale-kia? Binginatai lam atuli in-nako(9) at (11) itu aarde Middernacht toen mensch stelen zeven ma, lako deng lalan-ni, lè laok nako. Tia un neta- s, komen gaan langs weg om gaan stelen hij hij-ziet-ze ti noan: "ólet, mi(a) ma bua bèl(e) au (k)dale-ki lè!" zeg. vriend gijl. komen indoen geven mij aarde eerst

Ti atuli in-nako-ngias noan: "mò $\mathrm{ku}$ tam(a) nini (of: mini) mensch stelen zeg. nu gij ingaan liggen ( gij-ligt) sè bòlo-ka lè tao sa?" "A nòl(a) $(o f: \operatorname{mòl}(\mathrm{a})) \cdot \mathrm{au}$ in kuil om doen wat Spreken met gij-met) mij dèken, ta auk mate-ng sòn, mi(a) ma bua bèl(e) au djangan want ik dood- ik reeds gijl. komen indoen geven mij (k)dale-kia!" Tia atuli in-nako-ngias noan: "ku mate lò aarde mensch stelen zeg. gij dood niet bi, in-mate-(9) ka ellà lò." "Auk mate-ng, auk buin sòn- nò." nog dood zoo niet $\mathrm{Ik}$ dood- ik ik rieken reeds-ja Atuli in-nako-ngias noan: "ku mate lò, haung (hangu) Mensch stelen zeg. gij dood niet opstaan ma lè taok (16) (tako) lè- $\mathrm{t}$ nako!" $\mathrm{Ti}$ un haung (hangu) komen om gaan dat-wij stelen hij opstaan puti dèng bòlo-ki, ti òen palu-s laok ti sukun(17) uitkomen uit kuil zij acht-zij gaan breken kuimdòn uma. Tia at(11) itu-lias noan: "kit(a) sukun hidi resident huis zeven zeg. wij breken af bòlo sòn, ta $\mathrm{ku}$ laok tinang nuting (of: muting) kuimdòn gat reeds dus gij gaan kijken zoeken ( gij-zoekt) resident kaban-nias, hal(a) bèl(e) kami!" Tia un hal(a) - nal(a)(18) kist dragen geven ons hij dragen - hij-krijgt kaban itu, nin(i) bèl(e) atuli in-nako-ngias itu- $\mathrm{s}$ kaban kist zeven hij-brengt geven mensch stelen zeven-zij kist 
bak-memesa-s. Tia atuli in-nako-ngias itu- $s$ a nòla-n, elk- een -zij mensch stelen zeven-zij spreken met- hem naon: "kaim (kami) itu- $m$ kaban bak-memesa-m sòn mlia, zeg. wij zeven-wij kist elk-een -wij reeds dit mò ku nena- $\mathrm{m}$ bolan? $\mathrm{Ku}$ laok nuting (of: muting) maar uw eigendom-uw waar Gij gaan zoeken gij-zoekt) kaban mes(a) lè ku pake!" Tia tana (m)ngèngo-kia noan : kist een om gij gebruiken kind dom zeg. "mi(a) hal(a) lè lako-m, ta atuli-lias lubu- s lè nga gijl. dragen om gaan-gij want mensch hongerig-zij dat open baha-ns-sias mlia-sè." Ti un hos(a) ngae, ti hos(a) pèlo, mond-hun dit- ja hij koken mais koken pap ti sul(u) lè doan bèle- $\mathrm{s}$ sè baha-ns-sias, ti tenga-ki, ngae scheppen om gieten geven-ze in mond-hun helft mais laok kul(u) kò-ns-sias, ti mate-s, tenga-ki, ngae-la blingin gaan verbranden keel-hun dood-zij helft mais koud sòn, ta mate-s lò. Tia d̀en naskiut (naskitu) hangu-s, reeds dus dood-zij niet zij schrikken opstaan-zij hangu-s ti a: "mò $\mathrm{ku}$ ma tao sà?" Tia un noan : opst.- zij spreken nu gij komen doen wat hij zeg. "kaim (kami) ma lè-m nako, ta mi(a) blubu-(19) m, ta wij komen dat-wij stelen, wijl gijl. hongerig gij dus auk hos(a) ngae, lè nalo (of: kalo) mia." Ti òen dake- n, ik koken mais om voeren ( ik-voer) u-l. zij grijpen-hem dake-n ti laok buk(a) kuimdòn, ti kuimdòn hangu. Ti gr. hem gaan wekken resident resident opstaan

atuli-lias tek(a) kuimdòn, noan: "atuli mlia ma le nako, mensch melden resident zeg. mensch deze komen om stelen ti un hos(a) ngae nalo kami, ti kaim (kami) naskiut hij koken mais hij-voert ons wij schrikken (naskitu of maskitu) hangu, mò tenga-ku mate sòn." Ti wij-schr.) opstaan maar helft dood reeds

kuimdòm noan :" butu- $\mathrm{n}$ !" Tia òen butu- $\mathrm{n}$, ti sain resident zeg. binden-hem zij binden-hem ochtend nam presa- n. Presa-n noan: "ku ma tao sa?" Noan: toen onderzoeken-hem Ond.- hem zeg. gij komen doen wat. Zeg. "lò, auk mate-ng sòn, lamtua, mò auk laok kail (kali) neen ik dood- ik reeds, heer nu ik gaan graven bòlo, lè au kini-ng sè bòlo-ki dale, lam atuli in-nako kuil om ik ik-lig-ik in kuil binnen toen mensch stelen 
at (11) itu ma, ti au kodan lè bua bèl(e) au (k)dalezeven komen ik ik-vraag om indoen geven mij aarde

kia, lam òen tek(a) noan auk mate-ng lò; "ma lè toen zij melden zeg. ik dood-ik niet komen om

taok (16) (tako) lè- $\mathrm{t}$ nako sè kuimdòn uma, ma ti kaim gaan dat-wij stelen in resident huis komen wij

(kami) sukun-nal(a) (of: mala)(18) bòlo, tia òen tadu au breken-krijgen (wij-krijgen) gat zij bevelen mij

ma, lè hal(a) bèle- 's kaban itu, lè lako-s. Tia òen komen om dragen geven-ze kist zeven om gaan-zij zij

tek(a) au, noan: "ku kaban bolan?" Au teka: "lò, melden mij zeg. uw kist waar $\mathrm{Ik}$ zeggen neen atuli-lias lubu- s lè nga baha-ns mlia-sè." Ta auk hos(a) mensch hongerig-zij dat open mond-hun dit- ja Dus ik koken bèle- s ngae ale." Ti kuimdòn tadu pres(a) kaban; kaban geven-ze mais rijst resident bevelen onderzoeken kist kist

iut (itu) (m)nès, tadu laok tinang atuli in-doan (9) ngae zeven weg bevelen gaan kijken mensch gieten mais sè baha-ns-sias; at (11) dua mate-s. Tia kuimdòn noan : in mond-hun twee dood-zij resident zeg.

atuli-ngi ngèngo, sasao tali-las, butu- $\mathrm{n}$ baku-ma, (20) mensch dom losmaken touw binden-hem niet meer

ta ngèngo." Ti sao, ti kuimdòn, kéket: "atuli in-nakowant dom losmaken resident vragen mensch stelen ngias lako-s nin(i) ola?" Un noan: "auk tana-s lò, gaan-zij zij-brengen waar Hij zeg, ik kennen-ze niet lamtua!" "Ku net(a) (of: meta) òen uma tam lò? Au heer Gij zien (gij-ziet) hun huis of niet $\mathrm{Ik}$ keta- $\mathrm{s}$ lò, lamtua, òen ma lè haman au mlia binginatai, ik-zie-ze niet heer zij komen om roepen mij deze middernacht ta auk tan(a) lò." Tia tadu laok puan atuli mate-ngias dus ik kennen niet bevelen gaan begraven mensch dood dua-s, tadu atuli nuting atuli nako at(11) itu- lias, twee-zij bevelen mensch xij-zoeken mensch stelen zeven

bulan misa, mò neta- $\mathrm{s}$ lò. Tia tana ngèngo-kia, kuimdòn maand een maar zij-zien-ze niet kind dom resident noan: "ku dad(a) sè lia, bòel (bòle) in-laok (9) ola lò-ka." zeg. gij blijven te hier kunnen gaan waar niet Ti kuimdòn nuting bèle- $\mathrm{n}$ bihata lè sapa, tadu lè resident zoeken geven-hem vrouw om trouwen bevelen om 
dait (dati) klapa, dait (dati) hidi klapa-lia, tadu lè kòet hakken tuin, hakken af tuin bevelen om maken uma, kòet um(a) sè klapa-lia, tia bèle- $n$ dua-s sapa-ki huis maken huis in tuin geven-ze twee-zij vrouw talin nè sluku mesa, duit sèng. Kuimdòn noan: oehàt geld in zak een duit cent. Resident zeg. regentijd ma lam ulan-na nahu lam dua-m ku sapa-m $\operatorname{mos}(\mathrm{a})$ komen en regen hij-valt dan twee-gij uw vrouw-uw koopen ngae ale $\operatorname{nin}(\mathrm{i})$ (of: mini) duit-tas lè hai klapa-lia." Ti mais rijst brengen (gij-brengt) duit om steken tuin

oehàt, ulan-ni nahu, bihata-ngi lako naus ui, naus ui regentijd regen hij-valt vrouw gaan zij-draagt water zij-dr.- w. ti ma halas lò, ti ulan-ni nauh (hahu) ina isi. Ti tana komen snel niet regen hij-valt groot zeer kind ngèngo-ki noan: "bihata-ngi un ma tan(a) lò-ka lè hai dom zeg. vrouw zij komen weten niet om steken klapa-li lò." Ti un kò-(21)n mali nòl(a) sapa-kia, kat(a) tuin niet zijn keel zijn bitter met vrouw tillen duit-tias, laok hai klapa-li, hai hidi duit uunus mlia duit gaan steken tuin steken af duit hoop deze sòn ti sapa-ki sè ui ma. Ma ti noan: "au hai reeds vrouw naar water komen. Komen zeg. ik steken hidi klapa-la sòn." Ti bihata-ngi noan: "ku kat(a) ngae af tuin reeds vrouw zeg. gij tillen mais ael (ale) sà lè laok hai klapa-la?" "Mo kuimdòn bèl(e) rijst wat om gaan steken tuin En resident geven duit-tas lè hai klapa-lua, lò, mò ku lè tao sà?" Ti duit om steken tuin niet dan gij willen doen wat. bihata-ngi kò- $\mathrm{n}(21)$ mali ti laok tek(a) kuimdòn, noan : vrouw keel haar bitter gaan melden resident zeg. "lamtua, ku bèl(e) duit-tas lè sos(a) ngae alè lè hai heer gij geven duit om koopen mais rijst om steken klapa-lua, auk laok kaus ui, ti nesang ti ma lam tuin ik gaan ik-draag water lang komen toen ngèngo-ku kat(a) duit-tas laok hai hidi-s nè klapa-lu son." domme tillen duit gaan steken op- zij in tuin reeds. Tia kuimdon ngau bihata-ngia, noan: "ku tan(a) mamasu resident brommen vrouw zeg. gij weten goed lè atuli ngèngo-kia, mò $\mathrm{ku}$ laok maus ui kam nesang dat mensch dom en gij gaan gij-draagt water en lang 


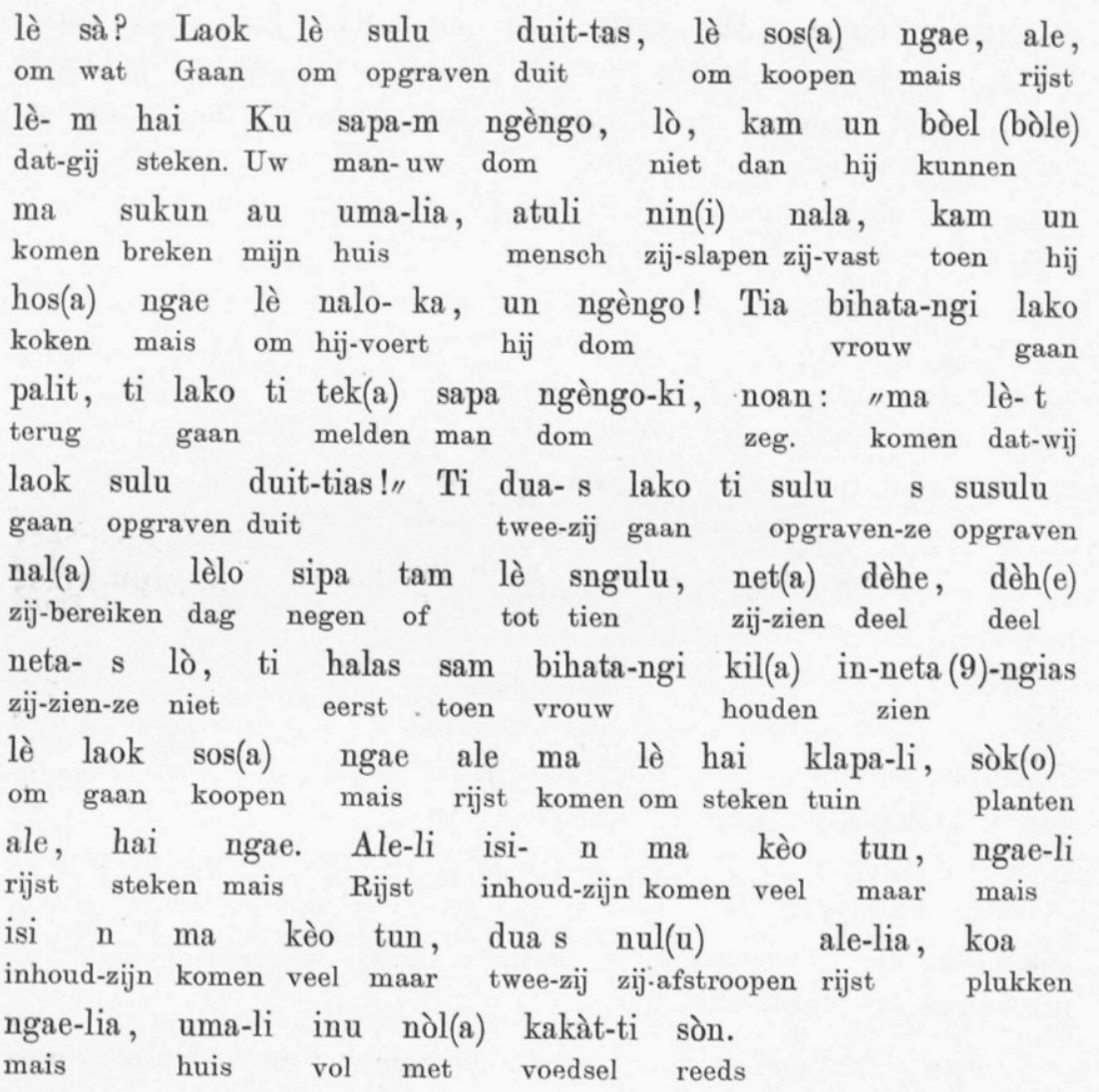

\section{Aanteekeningen.}

1. Evenals in het Rottin. en Timor. is ook in het Kupangsch het woord, dat wij door "met, en" vertalen, een werkwoord; dus: au kòl(a), ik ben met; ku mòl(a), gij zijt met; nòla, hij is (zij zijn) met. In het vervolg 'zal het eenvoudig door "met" worden weergegeven.

2. sapa, (Rottin. sao; Tag. asawa; enz.) beteekent als subst. "echtgenoot" (M. en Vr.); voor de kortheid schrijf ik: man of vrouw.

3. tia, bij verkorting ti, toen, vervolgens, enz.

4. Door achtergevoegde $\mathbf{s}$ wordt een meerv. te kennen gegeven: mate-s, zij zijn dood; dua-s, zij beiden; zoo ook achter het aangehechte voornw., dus: un ama-n, zijn vader; òen ama-ns, hunne ouders; un ina-ama-ns, zijne ouders.

Lia, of li bij verkorting, en la; van mlia, deze; mla, die, 
worden vrij wel dooréén als lidwoord gebezigd achter woorden, welke op eene vocaal eindigen; dus: uma-lia, uma-li, uma-la, het huis. Eindigt het voorafgaande woord op een medeklinker dan wordt de l van lia, li, la geässimileerd; dus: alas-sia, alas-si, alas-sa, het woud; ulan-nia, ulan-ni, ulan-na, de regen.

Er zijn evenwel ook woorden, welke thans op eene vocaal eindigen, maar oorspronkelijk door eene (in waarde gelijk aan de Rottineesche) $\mathbf{k}$ gesloten werden, bijv. upu, kleinkind, Rotin. upuk, (Bis. apú, enz.); na deze woorden is de uit de geässumileerde $\mathbf{l}$ van het lidwoord ontstane $\mathbf{k}$ gebleven, welke echter niet verdubbeld wordt, dus: upu-kia, upu-ki, upu-ka, het kleinkind. De meervoudsvorm is lias, las; uma-lias, uma-las, de huizen; alas-sias, alas-sas, de bosschen; (un) ina ama-ns-sias, de ouders van hem; upu-kias, upu-kas, de kleinkinderen.

Dezelfde waarde, na sommige woorden, heeft ngia, bij verkorting ngi, of ook wel ng, (over de verhouding tot lia enz. kan hier niet gesproken worden), bijv. bihata-ngia, bihata-ngi, bihata-ng, de vrouw; bihata-ngias, de vrouwen.

Een verdere afstand wordt aangeduid door lua, of lu, van mlua, gindsche, waarvan de $\mathbf{l}$ op dezelfde wijze behandeld wordt: umalua (lu), het (gindsche) huis; alas-sua (su), het (gindsche) bosch; uma-luas, de (gindsche) huizen.

5. upu, grootouders, naar omstandigheden: grootvader of grootmoeder, en ook: kleinkind (-zoon, -dochter).

6. De niet omgezette vorm van òne, zij, zijlieden, en de volledige vorm una, hij, zij, worden hierna niet meer aangegeven.

7. noan, zeggen, soms ook "willen, denken", of door "dat" weer te geven.

8. De niet omgezette vorm van lako wordt hierna niet meer aangegeven.

9. Met in worden verbale substantieven gevormd, in de beteekenis van: het doen, wat gedaan wordt of kan worden, en wie of wat doet, zoo bijv. in dit verhaal: bòel in-dati, kunnen (het) slaan; tan in-a, weten, kunnen (het) spreken; in-mate-ka, het dood, gestorven zijn; atuli in-nako, dief; in-ka, wat te eten is, voedsel.

10. sakeng, doen bestijgen, (van sake, klimmen), namenlijk: een schip, om iemand van Timor weg te voeren; vandaar sakeng verbonden met sòleng, (wegwerpen), verbannen. 
11. at dient tot hulptelwoord bij het tellen van menschen; blijkbaar hetzelfde woord als ata, wat nog in de beteekenis van "slaaf" in gebruik is.

12. niung, doen neerdalen, neerlaten; dit wordt gewoonlijk na vergelijkingen van hoogte gevoegd; in het Maleisch geven zij het weer door: kalau kasih turun, of kalau turun.

13. blalatas is de geredupliceerde vorm van blatas, lang. Andere dergelijke vormen in dezen tekst voorkomende, zijn: hohòso van hòso, stinken; lalaba van laba, snel; dadáda van dada, zitten; sasao van sao, losmaken.

14. sà-sà, (van sà, wat?) al wat iemand heeft, vandaar: goederen, bezitting.

15. lael in deze samenstelling uit lales, (Mal. lalat, enz.) vlieg.

16. takom, men zegt ook tako voor 't lako, wij gaan; de m in takom is duister.

17. suknn, eigenlijk: uit elkander nemen, uit elkander halen, vandaar: (een huis) afbreken, eene opening in een huis maken, door dat, waaruit de wanden, enz. bestaan, uit elkander te halen.

18. hala-nala, nala (in den $1^{\text {sten }}$ pers. kala, enz.) dient in zulke uitdrukkingen alleen om de handeling als voltooid aan te duiden, tegenover het pogen.

19. blubu voor lubu, alleen ingeval ook aan het pers. voornw. m gehecht kan worden, dus bij gebruik van ku, (gij); mia, gijlieden en kami, wij.

20. baku-ma, het is genoeg, het is niet meer noodig; ma is hierin nadrukwijzer.

21. De kò, keel, slokdarm, wordt als zetel van het verstand, gevoel enz. beschouwd, vandaar bijv. ku muik (muki) kò-m lò, hebt gij geen verstand? un kò-n mali, hij heeft een bitter gevoel in de kò, hij is boos.

\section{Vertaling.}

Er leefde eens eene vrouw met, haren man; zij baarde één zoon; daarna stierven beide ouders van het kind, dat alleen bleef met zijne grootmoeder, bij wie het in huis ging wonen.

Eens op een dag ging hij spelen en nam emmers mede om al spelenderwijs sagoeweer te tappen; er lag een hert, welks gewei hij 
voor een boom hield, waaraan hij de emmers ophing en wilde toen op het hert klimmen om sagoeweer te gaan tappen; maar het hert stond op en vluchtte weg. Het kind zeide: „broeder, wacht even, geef eerst mijne emmers!" Wat zou een hert daarop kunnen zeggen? Het vluchtte het bosch in.

Het kind ging heen en verhaalde aan zijne grootmoeder: "grootmoeder, ik ging heen en hing mijne emmers aan een boom, maar toen ik daarin wilde klimmen om sagoeweer te tappen, stond hij op en vluchtte en nam mijne emmers mede." Zijne grootmoeder sprak: "dat was een hert, als gij dat ziet, neem dan uw hakmes en dood het, want zulk een hert, dat geeft voedsel, vleesch." "Grootmoeder, morgen zal ik mijn hakmes medenemen, opdat, als ik een hert zie, ik het doode."

Den volgenden dag nam hij een hakmes en wilde het hert gaan zoeken, maar zag geen hert, maar wel kinderen ', die met elkaar vochten; hij ging daar op af en sloeg een der kinderen dood, dat hij naar zijn huis droeg.

Hij gaf er zijne grootmoeder kennis van: "grootmoeder, kom eens naar het hert kijken!" De grootmoeder kwam en zag toen dat 't een mensch was. $\mathrm{Zij}$ bromde op hem en sprak: "waarom hebt gij een menschenkind doodgeslagen? als de Compagnie (het bestuur) het verneemt, zal men u verbannen." "Grootmoeder, ik ging er heen, zij twistten samen, daarom doodde ik hem." "Als menschen met elkander vechten, moet gij ze scheiden, gij moogt ze niet dooden, anders zal men ons dooden."

Daarop sprak de jongen: "als ik morgen heenga en zie dat zij met elkander vechten, dan zal ik ze scheiden."

Den volgenden dag ging hij op weg en trof in een woud twee tijgers ${ }^{2}$ aan, welke met elkander vochten; hij wierp zich er tusschen om ze te scheiden, maar zij begonnen hem te verscheuren, zoodat hij overal gewond werd. Hij riep: "verscheurt mij niet, want mijne grootmoeder heeft mij gezegd, dat, als gij met elkander vecht, ik u moet scheiden".

1 Letterlijk: de (in het verhaal bedoelde) kinderen.

2 De tijger is bij overlevering op al de kleine Sunda-eilande bekend; de Rotineezen noemen hem mè-asu, een kat (zoo groot als) een hond. Omtrent de herkomst van het verhaal is uit het noemen van den tijger niets op te maken; eerder is, uit hetgeen verhaald wordt, aan te nemen, dat de tijger hier in de plaats van een ander dier, bijv. den buffel, is gekomen. Zoo :iets heeft dikmaals plaats; ik herinner mij een Sawuneesch verhaal, waarin gesproken wordt van iemand, die ,tijgers hoedt"! 
Maar hoe zouden de tijgers hebben kunnen spreken! Toen hij hen wilde scheiden, begonnen zij hem te verscheuren tot hij het niet meer kon uithouden, zich opmaakte en wegvluchtte. Toen hij bij zijne grootmoeder kwam, was zijn lichaam vol wonden. Zij zeide: "hoe komt het, dat gij zoo gewond zijt?" "Mijne grootmoeder heeft gezegd: "als gij menschen ontmoet, die met elkander vechten, ga ze dan scheiden". Toen ik nu op weg ging, ontmoette ik twee groote menschen, zóo groot, dat zij tot aan de goot van het huis reikten, en hunne nagels waren uiterst lang; zij nu waren bezig elkander te verscheuren; toen ik er tusschen kwam om ze te scheiden, begonnen zij ook mij nog te verscheuren."

De grootmoeder sprak: "dat hadt ge niet moeten doen; als gij ze ziet, vlucht dan; want dat zijn tijgers, geen menschen; hetzij gij ze ontmoet op de vlakte of in het woud, vlucht, want het zijn tijgers, zij zullen u anders verscheuren en dooden."

De grootmoeder maakte (geraspten) klapper warm om er de wonden mee te pappen. Toen sprak hij: "Grootmoeder, als mijne wonden genezen zijn en ik ga spelen en dan lieden ontmoet, die met elkandr twisten, dan vlucht ik."

Nadat zijne wonden hersteld waren, ging hij zich vermaken en kwam voorbij eenige huizen; de bewoners riepen hem aan en zeiden : "weeskind, kom hier om wat maïs te gebruiken".

Maar hij nam de vlucht en vertelde aan zijne grootmoeder : "grootmoeder, toen ik langs eenige huizen kwam, riepen zij mij aan en zeiden: "weeskind, kom hier, om wat maïs te eten", waarop ik hierheen gevlucht ben."

De grootmoeder sprak daarop: "als men u roept om maïs te eten, dan kunt gij dat doen, want dat komt ons dan toe."

"Morgen, grootmoeder, zal ik mijn klapperdop nemen en maïs gaan vragen, opdat, als ik terugkom, wij beiden er van eten".

Een volgenden dag ging hij heen en nam een klapperdop mede; maar hij liep de huizen mis, doch trof eene vrouw aan, die gebak verkocht; hij zeide tot haar: "geef mij wat maïs in mijn klapperdop." Zij sprak: "hoe kan ik 't u geven? ik heb hier geen maïs." "En waarom hebt gij mij dan gisteren geroepen om mij maïs te geven? Mijne grootmoeder heeft mij gelast een klapperdop te nemen, opdat gij mij maïs geeft."

De vrouw wilde hem geen maïs geven, waarop hij haar sloeg, zoodat zij neerviel; hij nam een steen op en sloeg haar daarmede de hersens in; toen nam hij de gebakjes en at ze op; daarna droeg hij 
de vrouw naar zijn huis en legde haar op zijne (slaap)plaats, zonder dat zijne grootmoeder het bemerkte. Na twee dagen begon de vrouw te rieken en legden de vleeschvliegen al te maal maden (zoo is de Kupangsche voorstelling) in haar, waarvan hij aldus sprak: "hoe heeft mijne vrouw zich toch met klapper ingesmeerd, geheel haar lichaam is vol uitgepersten klapper." Hij veegde de maden geheel weg, maar de vrouw stonk reeds.

De grootmoeder sprak: "hé, wat is het, dat zoo stinkt?" Hij zeide: "ik weet 't niet."

Zij wachtte totdat hij naar buiten was gegaan en ging toen zien in de slaapplaats van den jongen man, wat daar zoo stonk; en (zag) het reeds opgezwollen lijk van eene vrouw. Toen vroeg zij: "waarom hebt gij die vrouw gedood?" "Ik vroeg maïs en zij gaf mij die niet, daarom sloeg ik haar en viel zij; toen nam ik een steen op en sloeg (haar daarmede) en droeg ik haar hier alzoo heen om haar tot mijne vrouw te maken." "Om een lijk te trouwen? zij is immers zoo dood, dat zij al erg stinkt! Ga spoedig heen en haal eene schop om haar te gaan begraven."

Hij haalde daarop de schop.

De grootmoeder sprak: "ga een kuil graven; kom dan en neem haar op, om haar te gaan begraven."

Hij ging heen; nadat hij een kuil gegraven had, kwam hij terug. Toen sprak de grootmoeder: "wikkel haar in eene mat en ga haar begraven, anders, als de resident het te hooren krijgt, zullen wij straf krijgen." Hij wikkelde (het lijk) in de mat en ging het begraven.

Daarop kwam hij terug; na éen of twee dagen, toen hij met zijne grootmoeder te zamen zat, liet zij een wind. Toen sprak hij : "gij zijt dood, grootmoeder, gij riekt al". Zij antwoordde: "ik ben nog niet dood". "Jawel, gij riekt al". Zij zeide: "ik heb een wind gelaten, maar ik ben niet dood". Hij luisterde echter niet, nam eene schop en ging een graf graven aan de zijde van de vrouw, die hij begraven had; toen hij den kuil gegraven had, kwam hij terug; hij trok haar mede en sprak: "kom, laat ons gaan, ik ben al klaar met graven, uw kuil is klaar". Zij riep: "ik ben nog niet dood, ik liet een wind, daarom riek ik." Hij sprak : "neen, gij riekt juist zooals mijne vrouw."

De oude vrouw wilde niet gaan, maar hij sleepte haar voort en wierp haar in den kuil, nam een steen op en legde dien over den kuil en streek de aarde in den kuil. De oude vrouw deed niets dan schreeuwen in den kuil, maar hij ging maar voort met aarde er in te strijken tot de kuil vol was en de oude vrouw, na eenige stuiptrekkingen stierf. 
Daarop ging hij heen en kwam tehuis; alleen zette hij zich in huis neer om te mijmeren, en sprak: "zoowel mijne vrouw als mijne grootmoeder zijn dood; ik zit alleen hier in huis te suffen."

Nadat hij op die wijze een of twee dagen gezeten had, liet hij (zelf) een wind; hij sprak toen: "ik riek al, ik ben dood, ik riek nu als mijne vrouw en grootmoeder!" Daarop nam hij eene schop, ging heen en groef een kuil naast zijne grootmoeder; hij stapte er in en legde zich neder; maar wie zou er nu de aarde in werpen?

Te middernacht kwamen er zeven dieven, die langs dien weg liepen om te gaan stelen. Toen hij ze zag, sprak hij: "vrienden, schept even voor mij de aarde in den kuil." De dieven zeiden: " waarom : zijt gij in den kuil gaan liggen?" "Spreekt niet met mij want ik ben dood; komt hier en doet voor mij de aarde in den kuil." De dieven zeiden: "gij zijt nog niet dood, het doodzijn is niet alzoo." "Ik ben dood, ik riek toch al." De dieven spraken: "gij zijt niet dood; sta op en laat ons gaan stelen."

Toen stond hij op en kwam uit den kuil; vervolgens vertrokken zij met hun achten en maakten eene opening in het huis van den resident. ${ }^{2}$ Toen zeiden de zeven dieven: "wij hebben nu een gat gemaakt, ga gij nu kijken en zoek de kisten van den resident en breng ze ons!"

Hij droeg zeven kisten aan en bracht voor elk der dieven eene kist. De zeven dieven spraken met hem en zeiden: "wij hebben nu ieder eene kist, maar waar is nu de uwe? Zoek nog eene kist voor u."

De domme jongeling echter zeide: "neemt gij (uwe) kisten op den schouder en gat heen; de menschen hebben honger, zoodat hun mond zóó openstaat." (Bedoeld is dat de wakers bij het huis met open mond sliepen).

Daarop ging hij maïs koken en maakte er pap van, schepte ze op en goot ze hen in hunne keel; van eenigen verbrandde de maïs (pap) hunne keel, zoodat zij stierven; bij anderen was de maïs reeds koud(er), zoodat zij niet omkwamen. Zij schrikten toen wakker, stonden op en vroegen: "wat komt gij hier doen?" Hij zeide: "wij zijn komen stelen, maar wijl gij hongerig waart, heb ik maïs gekookt om u die toe te dienen." Daarop grepen zij hem en wekten

1 In vele verhalen bij de volken, die onder Timor ressorteeren, is de resident in de plaats van den vorst of ander voornaam persoon gekomen. Zoo wordt dan bijv. verhaald: een resident had zeven vrouwen, maar geen kinderen. 
den resident, waarop deze opstond. Zij vertelden hem: "deze man is gekomen om te stelen, daarna heeft hij maïs gekookt om ons die in te geven, waardoor wij zijn wakker geschrikt en opgestaan, eenigen echter zijn gestorven." De resident zeide: "bindt hem". Zij bonden hem; toen het ochtend geworden ,was, ondervroeg de resident hem en vroeg: "wat kwaamt gij hier doen?" Hij antwoordde: "niets; ik was dood, heer, en ben een kuil gaan graven om mij daarin neer te leggen; toen kwamen er zeven dieven, wien ik verzocht voor mij de aarde in den kuil te scheppen; zij beweerden echter, dat ik niet dood was (en zeiden): "komt, laat ons gaan stelen in het huis van den resident"; daar aangekomen maakten wij een gat in den wand en zij bevalen mij toen hier te komen en voor hen zeven kisten aan te dragen, waarna zij konden heengaan. Zij zeiden nog tot mij: "waar is uwe kist?" ik zeide: "neen, (nu kan ik daarvoor niet zorgen); de menschen zijn zóo hongerig, zoodat hun mond zóó openstaat". Toen kookte ik maïs en rijst voor hen."

De resident beval onderzoek te doen naar de kisten; zeven kisten waren verdwenen; hij beval te gaan zien naar de lieden, wien maïs (pap) in den mond gegoten was; twee waren er gestorven. De resident zeide: "de jongeling is een domoor, makt de touwen los, hij behoeft niet langer gebonden te zijn, want hij is een stommerik." Zij maakten hem los, waarop de resident hem vroeg: "waarheen zijn de dieven gegaan?" Hij sprak: "ik ken ze niet, heer". "Hebt gij gezien, waar zij. wonen?" "Ik heb 't niet gezien, heer; het was middernacht toen zij mij kwamen roepen, dus weet ik 't niet."

Er werd bevolen de twee menschen, die omgekomen waren, te gaan begraven, alsook om de zeven dieven te gaan zoeken; (men zocht) eene maand lang, maar vond ze niet. Toen sprak de resident tot den dommen jongeling: "blijf hier wonen, gij moogt niet meer overal heen zwerven."

De resident zocht eene vrouw voor hem om mee te trouwen, beval hem een tuin te ontginnen en nadat de tuin ontgonnen was, beval hij hem een huis te bouwen; hij bouwde een huis in den tuin, waarna de resident hem en zijner vrouw een zak centen gaf. De resident zeide: /lals de regentijd komt en de regen begint te vallen, ga dan voor dat geld, met uwe vrouw, maïs en rijst koopen om den tuin te beplanten", (door het steken van plantgaten).

Toen de regentijd $\mathrm{kwam}$ en de regen begon te vallen, ging de vrouw water aandragen, maar kwam daarmee niet spoedig terug; daarbij begon het hevig te regenen. Toen sprak de domme jongeling: 
"de vrouw is iemand, die niet weet, wanneer zij terug moet komen, zoodat zij den tuin niet beplanten kan." Hij werd boos op zijne vrouw, nam het geld en stak het in de plantgaten; nadat hij er op die wijze eene groote menigte ingestoken had, kwam zijne vrouw terug van het water halen. Hij sprak toen: "ik heb den tuin al beplant." Zij sprak: "wat voor maïs en rijst hebt gij gekregen om er een tuin mede te beplanten?" "De resident heeft immers centen gegeven om er den tuin mede te beplanten, wat wilt gij er anders mee doen?" De vrouw werd boos en ging 't den resident vertellen en sprak: "heer, gij hebt centen gegeven om daarvoor maïs en rijst te koopen om den tuin te beplanten; toen ik nu water ging aandragen en wat lang uitbleef, heeft die domoor de centen genomen en ze allemaal in de plantgaten gelegd."

De resident knorde op de vrouw en sprak : "gij weet heel goed dat hij een domoor is, waarom zijt ge dan heengegaan om water aan te dragen en zijt ge zoo lang uitgebleven? Ga de centen opgraven om daarvoor maïs en rijst te koopen om te planten. Uw man is een domoor; hoe had hij anders een gat in den wand van mijn huis kunnen komen maken, en terwijl de menschen vast sliepen maïs koken om ze dat in te geven; hij is immers een stommerik!"

Daarop ging de vrouw heen en sprak tot haren onnoozelen man: "kom, laten wij de centen gaan opgraven!"

Dat deden ze en groeven negen of tien dagen lang; een gedeelte vonden zij, een ander gedeelte niet; de vrouw nam de centen, welke zij gevonden hadden, en ging daarvoor maïs en rijst koopen.

Toen zij terugkwam, beplantten zij den tuin met rijst en maïs. Zoowel de rijst als de maïs droegen overvloedig vrucht, en beiden oogstten de rijst en plukten de maïs en het huis was vol voorraad.

Ook in het Timoreesch is mij eene, zij het ook zeer lakonieke en onvolledige lezing van het verhaal bekend.

In het voorbijgaan zij opgemerkt, dat 't mij, bij de Timoreezen, bijna nooit mocht gelukken dergelijke overgeleverde verhalen te verkrijgen, waarmede ik evenwel niet zeggen wil, dat zij niet zouden bestaan; vertellingen van eigen vinding en verdichting gaven zij mij meer.

Dat mij het verhaal in het Rottineesch niet bekend is, is wel toevallig.

Het Timoreesche verhaal luidt als volgt: 
Atondjes (uit: atoni es ) nòk (1) fel-(2) (1)an maihoni (3) mensch een) met vrouw die baren

an-(uit: anah) mònel- (1)es, mes akoüt. Es (4) sin ek- nan (5)

kind mannelijk een maar dom zij sluiten-zij-bereiken bi kè' nes. (uit: kèën es). Nan ton bò nua nes(i) (6), in kamer een Hij-bereikt jaar tien twee meer

es in hè sao bifèl-(l)es, mes bifèl-(l)i ka-n lomi, hij willen trouwen vrouw een maar vrouw deze niet-zij willen es nèsgwe (uit: nèso è ), ma-n mat(e). Es in naskau hij-slaat haar en-zij dood hij hij-draagt natàm bi in kèën, nan nènog ten $(u)$, in nafò. hij-brengt in in zijn kamer het-bereikt dag drie zij zij-riekt Es ainaf amaf nak: "sàän nafô bi kèën nanan?" In moeder vader zij-zeggen wat-dat het-riekt in kamer binnen Hij

nak: "au fèl." Es ainaf amaf tam kiso, es sin nao hij-zegt mijn vrouw moeder vader ingaan kijken zij gaan hani nopu ma-n sub. Meu ainfi (uit: ainaf i ) naskui graven kuil en- zij begraven Morgen moeder deze zij-veest hè nafò, es in nao hani nopu ma sub- (b)è nòk-a (7) dat zij-riekt hij gaan graven kuil en begraven haar met honis. Meu 'n (voor: an) ten(i); es amfi (uit: amaf i ) levend Morgen het weder vader deze naskui ma mafò es in nak: "ama maten (uit: mate en ). hij-veest en hij-riekt hij hij-zegt (mijn) vader dood reeds "Es in nao hani nopu ma nait(i) amfi (amaf i ), kak-kak hij gaan graven kuil en hij-tilt vader deze schreeuwen mes in sub- (b)è. Es in naskui ma nafò, es in nao maar hij begraven hem hij hij-veest en hij-riekt hij gaan hani nopu ma tam ma ka- $\mathrm{n}$ kub in-a(7) naka-n. graven kuil en ingaan en niet-hij bedekken zijn hoofd-zijn Es atoni nua nem, es sin hel napoin. mensch twee zij-komen zij trekken zij-doen-uitkomen.

\section{Aanteekeningen.}

1. Nòk, vgl. Aant. 1 bij den Kup. tekst.

2. Fel, echtgenoote; bifèl, vrouw, vrouwelijk; fel-(l)an, uit: fel en an, die, de; dergelijke verdubbelingen van den slotmedeklinker staan hier tusschen haakjes.

3. Maihonis; de ai is hier een echte tweeklank, dus éenletter- 
grepig; zoo ook in: ainaf, M.-P. ina. E en o op het einde klinken als è en ò, zooals in het Kupangsch.

4. Es, toen, vervolgens, daarom, enz.

5. Nan, Kup. nala, zie aldaar, Aant. 18.

6. Nes(i); eene tusschen haakjes geschreven vocaal aan het einde van een woord duidt, in dit Timoreesch stukje, aan, dat zij, hoewel niet geheel weggevallen, toch nauwelijks hoorbaar is; dit vindt plaats, wanneer het woord op het einde van eene zinsnede komt te staan, enz., dus iets geheel anders dan het weggevallen van de eindvocaal in het Kupangsch.

7. Nòk-a honis; de a, hoewel eigenlijk tot het woord behoorende is hier meer een overgangsklank, evensals beneden in in-a uaka-n.

\section{Vertaling.}

Een man en zijne vrouw gewonnen éen zoon; maar hij was een domoor; waarom zij hem in een kamer opsloten. Toen hij meer dan twintig jaar oud was, wilde hij eene vrouw trouwen, maar de vrouw wilde niet, waarop hij haar sloeg, waardoor zij stierf. Hij nam haar op en bracht haar in de kamer; na drie dagen, stonk zij. Toen zeiden zijne ouders: "wat riekt toch zoo in de kamer? Hij zeide: "mijne vrouw." Daarop gingen zij kijken; vervolgens gingen zij een graf graven en begroeven haar. Den volgenden dag, liet de moeder een wind en stonk daardoor; de zoon ging een graf graven en begroef haar levend.

Den daaropvolgenden dag, liet zijn vader een wind en stonk; de zoon sprak: "vader is dood." Hij ging een graf graven, nam zijn vader op, en hoewel deze steeds schreeuwde, begroef hij. hem.

Daarop liet hij (zelf) een wind en stonk, waarop hij een graf ging graven en er in ging, maar zijn hoofd niet bedekte. Toen kwamen er twee personen en haalde hem er nit.

Hetgeen in het Toradjasch verhaald wordt van Mariala, hoe hij een lekker kostje klaarmaakten, en den lieden wijsmaakten, dat het hondendrek was, (t. a. p. pag. 123, vlg.). is mij, in eene eenigszins andere lezing, alleen in een Sumbawareesch verhaal bekend.

Om dezelfde redenen als boven bij het Kupangsch vermeld, moge hier een klein gedeelte van den tekst volgen, eveneens met interli- 
neaire vertaling. Het accent valt bij het Sumbawareesch uitsluitend op de laatste lettergreep.

E en $\mathbf{0}$ aan het slot klinken gewoon, tenzij anders is aangegeven.

Ada sa-nompo tau miskin, ada anak sopo ba-singin (1) Zijn een-stuk mensch arm zijn kind een naam

Salam, ia-(2)antat ngadji(3). Dadi(4) ling dalam ngadji hij-brengt

di dalam

ba-ling dĕngan: "kuda lè mu-datang ngadji? Ku-beang woord makker waarom laat gij-komt Ik-geven

mè asu ode-ku." "Kuda mu-patik asu, apa nĕdjis?" Dadi nasi hoind klein-mijn Waarom gij-houdt hond want onrein

ba-ling-mo (5) guru: "na patik asu, Salam, apa nĕdjis!" woord meester djangan houden hond want onrein

Dapat bale Salam: "e ina, sia-(6)tudja aku baso, olo bereiken huis moeder gij stampt mij mais, doe bij gula ke njir, (4) apa ia (2) ku-bawa lalo ngadji nawar.” suiker met klapper want ik-breng gaan morgen Ba-langan-mo Sala lalo ngadji, dĕngan rame ngadji, Salam weg gaan makker ramai

kakan baso. Dadi ba-ling guru: "apa de mu-kakan kau, eten mais woord meester wat dat gij-eet gij Salam, bua, no mu-ngadji?" "Kadji-(8) kakan tai asu hoe niet gij ik eet drek hond ode." "Njaman-ke, Salam, tai asu ode?" Dadi ba-ling klein Lekker- kah drek hond klein woord Salem: "n jaman, guru." "Maeng gadu aku rasa!" Ia-beanglekker meester Welaan tjoha ik proeven hij-geeft

mo ling Salam lako guru, mĕngka ia-kakan-mo ling guru: door aan meester toen hij-eet door meester "e njaman tai asu ode, Salam, beang aku sopo, Salam, lekker drek hond klein geef mij een

amè no- mo kangompa guru- mu pina těpong." Dadi opdat niet meer moede meester(es)-uw maken meel

ia-beang-mo ling nja (9) Salam asu ode sopo lako guru. hij-geeft door hond klein een aan meester "Apa mè asu ode ta, Salam?" Dadi ba-ling Salam lako Wat voedsel hond klein deze woord an guru: mè ke gula ke n jir tu-beang." (10) "Me- lok meester nasi met suiker met klapper wij-geven Mama wijze 
lamin tu-ete tai?" "Tu-ĕnti nè tu-ěnti ima, karing als wij-nemen drek Wij-houden poot wij-houden hand, blijven tu-ampar, tu-sangka ke pingan lis tai asu ode nan." wij-slaan wij vangen op met bord uitkomen drek hond klein die

Dadi ĕnti -mo ling kotap, Salam lalo èneng ai- kawa houden door leerling gaan vragen water-koffie

lako guru, ba-tĕris-mo ba-rari Salam. Dadi ba-ling guru: aan meester(es) tĕrus lari woord meester "lalo kĕlek Salam bawa ai-kawa lèma!" Dadi lalo-mo gaat roepen brengen koffie snel gaan

kotap, èneng-mo ai-kawa lako guru sowai, Salam ka-mo leerling vragen koffie aan meester vrouwelijk reeds ba-rari. Dadi inim ai-kawa guru, mutu ia-sidu tai lari drinken koffie meester, toen hij-schept-op drek asu ling guru, ia-pamung baung, ia-bolang. Ngarai hond door meester hij-ruikt stank hij-werpt-weg Boos

guru: "lalo buya Salam, amè tu-samate." (11)

meester gaat zoeken opdat wij-dooden.

\section{Aanteekening.}

1. Ba-singin (zoo geschreven voor de duidelijkheid) $=\mathrm{Mal}$. bĕrnama. Dezelfde functie heeft het voorvoegsel ook bij alle in den boven-gegeven tekst voorkomende woorden. Het kan evenwel in het Sumbaw. ook voor andere verbale woorden dan in het Mal. voorkomen, wanneer zij intrans. gebezigd worden; bijv. ba-sura-mo datu, de vorst beval. Voor vocalen luidt het nog: bar: barutang; Mal. běrhutang; voor lipletters wordt het door ra vervangen: ra-bua, Mal. bĕrbuah.

2. Ia-antat, hij, zij geleidt, of zij geleiden; deze vorm komt alleen voor bij transitieve verba (ook dan kan ia verzwegen worden), toch kan men moeielijk van een passief spreken; vgl. bijv. datu kèmas ia-mĕnong pangkĕling nan, de vorst glimlachte toen hij dat woord hoorde.

Bij intransieven wordt de derde pers. niet verder aangeduid, doch de overige personen luiden bijv.: ku-balayar, ik zeil; mu-balayar, gij zeilt, enz. En dat dit eene innige verbinding is van het voornw. met het verbale woord, blijkt reeds daaruit, dat mu geen zelfstandig bestaan heeft, wel kau; ook ia niet, in de beteekenis van "hij. zij; (ku zou desnoods als een verkorting van aku kunnen beschouwd worden). Toch kunnen de volledige voornw. wel in de plaats van de 
verkorte vormen treden. Naar omstandigheden kan zoowel mu-njurat als mu-surat (gij schrijft) voorkomen.

Van dit ia is te onderscheiden dat, wat verderop in ia kubawa voorkomt; het laatstgenoemde kan door "om, om te" weergegeven worden en moet voor een werkwoord door ons met "willen" overgezet worden; dus: ia ku-bawa, ik wil brengen; zoo ook voor intransitieven: ia lalo, hij wil gaan.

\section{Ngadji, Mal. mĕngadji.}

4. Dadi, geschieden, en v. d. het geschiedde, toen, vervolgens.

5. Mo, nadrukwijzer als in het Makassaarsch.

6. Sia, voornw. van den $2^{\text {den }}$ pers., iets beleefder dan kau; 't beleefdste is kĕlam, (waarvan de oorsprong mij duister is). Bij nog nederiger wijze van spreken, treden, evenals in het Mal. enz., subst. in de plaats van het voornw.

7. Hoewel voor het verstaan niet bepaald noodzakelijk, merk ik even op, ter verklaring van den vorm njir, (Mal. njiur, enz.), dat eene $\mathbf{u}$ in het Sumbaw. in de laatste lettergreep, (behalve voor de ng), overgaat in eene korte $\mathbf{i}$, terwijl door het accent op de laatste lettergreep, de voorafgaande vocaal weggeworpen wordt, zoo bijv. ook lit, Mal. lant.

8. Kadji , (van adji, vorst, heer, dus geheerd, een heer hebbend), nederig voor aku. Nog nederiger is kadjulin, dat duidelijk ulin (voor uluu), slaaf, bevat en misschien kadji, zoodat het eene samenkoppeling zou zijn. Dergelijke voornw. treden steeds geheel in de plaats van de verkorte voor verbale woorden; men kan in het Sumbaw. dus wel zeggen: aku ku-kakan, of aku kakan, evenals in het Bimaneesch nahu ku-ngaha, of nahu ngaha; doch in het Sumbawareesch niet, evenals in het Bimaneesche lamada ku ngaha: kadji ku-kakan, maar alleen kadji-kakan.

9. Nja, lidwoord bij namen van mannen.

10. Tu-beang, wij geven; tu, uit tau, eigenlijk "mensch", maar in het Sumbaw. ook als voornw. gebezigd in de beteekenis van Mal. kita. Dikmaals gebruikt waar wij "men" zouden zeggen.

11. Het Sumbaw. vormt causatieven met een prefix să: samate, dooden; sabrěsi, schoonmaken; soms wordt het door een neusklank gesloten, bijv. sangita, (voor sanggita van gita, elders kita, ita), laten zien; sangěntèk, (van ěntèk), naar boven brengen. 


\section{Vertaling.}

Er was eens een arm man, die een zoon had, Salam geheeten, dien hij naar school deed gaan. Tusschen het leeren door, zeiden zijne makkers: "waarom komt gij zoo laat op school?" "Ik heb mijn hondje eten gegeven." "Waarom houdt gij er een hond op na, daar die toch onrein is?" Ook de meester zeide: "houd er geen hond op na, Salam, want die is onrein."

Thuis gekomen, zeide Salam: "moeder, stamp, als 't u belieft, voor mij wat maïs, en doe er suiker en klapper bij, want dat wil ik morgen naar school medenemen."

Salam ging naar school; terwijl zijne makkers met hun allen aan het oplezen waren, zat Salam maïs te eten. Toen sprak de meester: "wat eet gij daar, Salam; waarom leest gij niet mee?"

"Ik eet den drek van een hondje."

"Is dat lekker, Selam, de drek van een hondje?"

Salam sprak: "lekker, meester."

"Kom, laat mij eens proeven!"

Salam gaf het aan den meester; toen deze er van gegeten had, (zeide hij), "hé, wat is die hondendrek lekker, Salam; geef mij ook een (hondje), Salam, opdat uwe meesteres, (mijne vrouw), zich niet meer behoeft te vermoeien om meel te maken."

Salam gaf daarop een hondje aan den meester.

"Wat geeft gij zulk een hondje te eten, Salam."

Salam zeide tot den meester : "rijst met suiker en klapper geven wij."

"Hoe gaat 't als wij den drek willen gebruiken?"

"Wij houden (men houdt) zijne voor- en achterpooten vast en dan heeft men hem alleen maar te slaan en den drek, bij het uitloopen, in een bord op te vangen."

De leerlingen hielden nu (den hond) vast en Salam ging (zoogenaamd) koffie vragen aan (de vrouw van) den meester, maar nam meteen de vlucht. De meester sprak: "Gaat heen en roept Salam, dat hij snel de koffie brenge!"

(Een) leerling ging heen en vroeg aan de meesteres (de vrouw van den meester) om koffie, want Salam was al gevlucht. De meester dronk de koffie, maar toen hij den hondendrek opschepte, rook hij den stank en wierp den drek weg. De meester werd toornig (en sprak: "gaat Salam zoeken, opdat wij hem dooden!"

Het verhaal wordt als volgt voortgezet: dewijl Salam niet te vinden is, laat de meester eene koe, welke onder het huis staat 
weghalen en slachten. Salam weet de huid machtig te worden en klimt daarmede in een boom. Toevallig verzamelen zich eenige dieven onder dien boom om daar hun buit te verdeelen; Salam laat de huid plotseling vallen, waardoor de dieven vluchten en Salam zich van het geld meester makkt. Hij laat nu driehonderd rijksdaalders naar den meester brengen met de boodschap, dat dit de opbrengst van de huid is.

De meester laat nu al zijne eigen koeien slachten, doch krijgt slechts éen gulden per huid. Als Salam nergens te vinden is, steekt de meester uit wraak diens huis in brand. Salam verzamelt de asch, klimt in een boom, wasronder zich weder dieven neerzetten, die hij door het uitstrooien der asch verjaagt, waarna hij zich al hun goud toeëigent. Een gedeelte van dat goud zendt hij aan den meester als opbrengt van de asch van het verbrande huis. De meester steekt nu ook zijn eigen huis in brand, maar kan hoogstens twee centen per zak asch bedingen. De meester zoekt nu Salam overal totdat hij hem ten slotte vindt in gezelschap van zijne schoonmoeder en zijne vrouw, de laatste heeft hij in eene mat gerold. De meester ziet de schoonmoeder voor Salam's vrouw aan en vraagt, waarom hij zulk eene oude vrouw genomen heeft. Salam zegt, dat het hem niets hindert, daar hij een stok heeft, waarmede hij eene oude vrouw tot eene jonge kan slaan. Vlug laat hij zijne schoonmoeder verdwijnen, slaat op de mat, waaruit dan zijne jonge vrouw te voorschijn komt. De meester verzoekt hem natuurlijk dien stok te mogen hebben, welken Salam hem geeft op voorwaarde, dat hij niet meer zal trachten hem te dooden.

Tehuis gekomen slaat de meester nu zijne eigen vrouw met dien stok, tot zij er onder bezwijkt.

Het verdere verloop van het verhaal is dus geheel verschillend van het Toradjasche. Hetgeen daarin evenwel verhaald wordt, hoe de held bewerkt dat een ander in zijne plaats gedood wordt en hoe hij-zelf zich later voordoet als uit het doodenrijk teruggekeerd te zijn, enz., wordt ook in hoofdtrekken medegedeeld in het Bimaneesche verhaal van la Kalai.

(Bimaneesche texten, pag. 21. vlg.), waarvan hier eene vertaling volgt.

$$
\text { Verhal van Kalai. ') }
$$

Er was, naar men verhaalt, eens iemand, die Kalai heette; hij

1) Kalai beteekent: ander, anders, la Kalai kan door: „de(n) Zonderling” weergegeven worden. 
bezat een tuin aan het zeestrand. Toen (eens) ging hij heen en beklom een klapperboom in dien tuin. Er was evenwel ook een prins, die daar met een vaartuig voorbij voer. De prins sprak nu: "he, Kalai, klim niet in mijn klapperboom; als gij er (verder) inklimt, zal uw vader sterven; daalt gij af, dan sterft uwe moeder; blijft gij in 't midden, dan sterft gijzelf. Als Kalai hoorde, wat de prins zeide, (dacht hij): "dan moet mijn vader maar sterven." Daarop klom hij hooger in den klapperboom, wierp al de vruchten naar beneden, ging zelf de vruchten achterna naar beneden, nam ze op om ze te dragen 'en keerde naar huis terug. Daar aangekomen, zag hij, dat zijn vader en zijne moeder beiden nog (in leven) waren.

Toen sprak hij: "die prins heeft gelogen." Hij liep zoo snel mogelijk naar zijn tuin en riep den prins toe: "hé prins, als gij den steven naar buiten (zeewaarts) wendt, zult gij schipbreuk lijden; vaart gij naar binnen (landwaarts), dan zult gij verdrinken."

De prins sprak tot zijn mbòda ${ }^{1}$ ) "mbòda laat den steven wenden, laten wij zeewaarts gaan; het is beter dat wij schipbreuk lijden, dan dat wij verdrinken."

Zij wendden den steven en voeren zeewaarts. Nadat zij nog niet lang zeewaarts gevaren hadden, leed het vaartuig van den prins werkelijk schipbrenk; al zijne volgelingen kwamen om, alleen de prins en de mbòda bleven gespaard, doordien zij zich aan eene plank van het vaartuig boven water hielden. Nadat zij aan land gekomen waren, zeide de prins: "neem dat stuk van eene plank op uwe schouders en ga heen en geef het aan Kalai, en (zeg hem): de prins heeft met zijn vaartuig schipbreuk geleden; maak van dit stuk plank nu voor hem een klein en een groot schip, eene kleine en eene groote brik, een kleinen en een grooten schoener; binnen zeven dagen moeten zij klaar zijn."

Kalai antwoordde: mbòda, ik neem op mijn hoofd en op mijne schouders (ik neem eerbiedig op mij) wat de prins bevolen heeft; maar ik heb geen gereedschap om een schip of brik te maken; ga nu voor mij dit stuk naald aanbieden met verzoek daarvan voor mij te maken eene kleine en eene groote zaag, een kleinen en een grooten dissel, een kleinen en een grooten beitel, eene kleine en eene groote boor, een kleinen en een grooten hamer en alle werktuigen, waarmede een vaartuig gemaakt wordt."

1) Mbòda is de titel van den voornaamsten dienaar van een rato of prins, die zijne bevelen overbrengt. 
De mbòda keerde terug, maakte zijne opwaehting bij den prins en deelde hem mede, al wat Kalai gezegd had, hoe hij op zich genomen had schepen en brikken te maken; maar: "hij heeft geen gereedschap, o heer; hier is een stuk van eene naald, waarvan hij verzoekt alle gereedschappen voor het bouwen van een vaartuig te maken."

De prins werd toornig toen hij één stuk van eene naald zag, waaruit hij zoovele gereedsehappen moest maken; hij zeide wederom : "mbòda, ga heen en breng nog eens dezen steen, beveel hem daaruit voor mij een schip te maken, dat binnen drie dagen moet klaar zijn."

Daarop ging de mbòda naar Kalai.

Deze vroeg: "welke tijding brengt gij, mbòda?"

De mbòda sprak: "de prins heeft mij bevolen dezen steen te brengen, maak daarvan, naar hij gezegd heeft, een schip, dat binnen drie dagen reeds klaar moet zijn."

Kalai zeide: "ik neem aan, wat de prins bevolen heeft."

De mbèda keerde terug om den prins mede te deelen: "hij heeft den steen neergelegd en op zich genomen daaruit een sehip voor u te maken."

De prins sprak: "als er drie dagen verloopen zijn, ga dan het schip halen."

Daarop ging de mbòda naar zijn huis.

$\mathrm{Na}$ verloop van drie dagen ging de mbòda wederom naar Kalai (en sprak): "ik kom op last van den prins om het steenen schip te halen."

Kalai antwoordde: "het steenen schip is al geheel klaar; in twee dagen heb ik het gemaakt; maar het heeft nog geen anker."

Kalai gaf hem een klapperdop vol zand: "breng dit aan den prins en verzoek hem daarvan een anker te maken, opdat men het vaartuig kan doen ankeren."

De mbòda ging den klapperdop met zand brengen. Hij sprak: "heer, het steenen vaartuig is klaar, in twee dageh slechts heeft Kalai het gemaakt; maar het heeft nog geen anker; hier is een klapperdop met zand, welken hij mij bevolen heeft aan u te geven, opdat u daarvan een anker er voor make."

De prins werd, dit hoorende, toornig: "ga en zeg hem, of zijne moeder of zijn vader hem geleerd heefd een anker van zand te maken! Hoe kan 't toch met zand; zoodra dat met water in aanraking komt, gaat het uit elkander."

De mbòda, ging weer naar Kalai toe en zeide: "heeft uw vader 
of uwe moeder u geleerd, Kalai, om een anker van zand te maken; dat vraagt de prins." Kalai antwoordde: "zeer vele eerbetuigingen worden gebracht onder aan de voetzolen en hielen van den prins, maar heeft ook de moeder of vader van den prins hem geleerd een steenen schip te maken!"

De mbòda bracht over wat Kalai gezegd had. Toen de prins dat vernam, werd hij toornig op Kalai (en sprak): "ga heen en bind dien hond; als gij hem gebonden hebt, breng hem dan naar het bosch, daar zullen wij hem in aller tegenwoordigheid verbranden!"

Een menigte mannen gingen heen om Kalai te grijpen en te binden, en brachten hem naar het woud. Aldaar aangekomen, begon het avond te worden. De prins sprak: "voor heden is het verbranden van Kalai mislukt; morgen zullen wij hem verbranden."

Men bond hem aan een boom, waarop de prins met zijne volgelingen naar huis terugkeerde, zoodat Kalai alleen bleef.

$\mathrm{Nu}$ was er een Javaansche (vreemde) vorstenzoon, wiens verloofde gestorven was, waardoor hij eenigzins aan het malen geraakt was; hij nu kwam langs Kalai, en zeide: "vriend, wat voert ge daar met uzelf uit?"

Kalai antwoordde: "ik ga trouwen met de dochter van een prins; maar ik ben wat stijf, daarom ben ik hier om mijn lichaam wat leniger te maken."

De vorstenzoon sprak: "mijn vriend, laat ik in uwe plaats met die prinsendochter trouwen."

Kalai zeide: "dat kan niet, want ik heb al veel onkosten gemakt en die dochter van den prins is zeer schoon; haar vel is mooi geel van kleur, hare haren zijn zoo lang, dat zij tot aan hare hielen reiken; er is niemamd die haar in schoonheid evenaart."

De vorstenzoon zcide: "vriend, heb medelijden met mij, geef mij uwe verloofde, neem al wat ik aan heb, mijne met goud beslagen krisscheede, mijn krisband van roode zijde, mijn buikband van gebloemde zijde, mijn hoofddoek van met gouddraad doorweven zijde, mijn kain van dezelfde stof met een kapala van kĕmbayat, neem dit alles te zamen!"

Kalai sprak daarop: "als 't er zoo mee staat, goed dan; maak mij dan maar los." De vorstenzoon bond hem los. Daarna trok hij uit, al wat hij aan had en gaf het aan Kalai; zelf trok hij de kain en het baadje van Kalai aan, welke geheel versleten waren. Kalai bond hem vast aan denzelfden boom, waaraan hij gebonden was geweest. Kalai ging daarop naar huis; de vorstenzoon bleef alleen in het bosch. 
Den volgenden dag $\mathrm{kwam}$ de prins met zijne volgelingen; sommigen droegen hout, anderen brachten vuur aan; toen zij kwamen aan de plaats, waar (hij, dien zij hielden voor) Kalai zich bevond, wilden zij hem gaan verbranden.

De vreemde vorstenzoon schreeuwde: "ik ben niet Kalai!"

De prins sprak: "luistert niet naar hetgeen dien hond zegt; wie zou gekomen zijn om zich in uwe plaats te stellen? Verbrandt hem, jongens!"

Daarop verbranden zij hem; zijn hoofd (schedel) sprong met een knal uiteen. Allen keerden daarna naar huis terug.

Drie dagen nadat de verbranding had plaats gehad, trok Kalai de geheele uitrusting van den vreemden vorstenzoon aan, en ging naar de markt, terwijl hij drie granaatappelen en een peperhuisje met sirih-pruimen bij zich droeg; zoo ging hij midden op de markt staan.

De mbòda van den prins was nu ook op de markt. De mbida sprak : "zijt gij hier (weer terug) uit het doodenrijk?"

Kalai sprak: "ja, ik ben hier weer; ik wil mijne opwachting gaan maken bij den prins."

De mbi da zeide : "wacht even, ik zal 't eerst den prins mededeelen."

Daarop liep de mbc̀da zoo snel hij kon naar den prins om het hem te verkondigen; hij sprak : "heer, Kalai is (hier weder) gekomen !"

De prins zeide: "gij liegt, beest van een mbòda, hoe zou 't mogelijk zijn, dat Kalai terug gekomen is, terwijl hij verschroeid is en zijn hoofd uiteengespat is!"

De mbòda sprak: "ik lieg niet, heer; Kalai is er werkelijk, hij is gekleed met een hoofddoek en kain van met gouddraad doorweven zijde; een met goud beslagen krisscheede, een krisband van roode zijde; hij staat met de handen op den rug op de markt; hij heeft granaatappelen bij zich en nog iets, ik weet niet wat, in een peperhuisje./"

De prins zeide toen: "ga hem voor mij roepen!"

De $m b \grave{d} a$ ging Kalai roepen.

Kalai maakte daarop zijne opwachting bij den prins; daar aangekomen, riep de prins hem tegemoet: "kom Kalai, wat voor nieuws brengt gij van het doodenrijk?"

Kalai sprak: "heer, daar ontbreekt niets; alles wat (wèl) luidt, alles wat eetbaar of drinkbaar is, alles waarmede men zich kleeden of bedekken kan, is daar in overvloed aanwezig; man kan er geen voorbeeld van geven, hoe overvloedig het daar is; dit, wat ik 
aanheb, is mij gegeven door uwe voorvaderen; ik kom, wijl ik door hen gezonden ben om $\mathrm{u}$ te komen halen; zij verlangen zeer naar $\mathrm{u}$; ga toch zoo vlug mogelijk; het is nu geen tijd van zitten, maar van opstaan; op deze wijze spraken uwe voorvaderen."

De prins weende toen hij de door Kalai overgebrachte woorden hoorde, en sprak: "gaat heen en verzamelt hout om mij daarmede te verbranden; ik wil terstond naar het doodenrijk heengaan!"

De mbòda en de volgelingen gingen hout halen; toen dat geschied was, gaven zij er den prins kennis van : "het hout is bijeengebracht, heer!"

De prins sprak: "verbrandt mij heden avond met u allen."

Hierna begaf ieder zich naar huis.

Toen het avond werd, ging Kailai wederom op weg om den prins te roepen.

De prins makte zich gereed om met den mbòda en al zijne dienaren en onderhoorigen naar het bosch te gaan.

Daar stapelden zij al het hout, dat er bijeen was, op en staken het aan; toen het goed vlamde, sprongen allen den prins achterna in het vuur met een licht hart, omdat zij het land der dooden verlangden te zien. Hunne hoofden (schedels) spatten uiteen; zij werden door het vuur verteerd en stierven.

Kalai nam de dochter(s) en echtgenoote(n) van den prins tot vrouw; zijne huizen en gebouwen, zijne erven en gronden, dat alles nam Kalai. - Einde.

In eene, overigens geheel anders luidende, Sawuneesche vertelling omtrent zekeren Pepeka, wordt eveneens verhaald, hoe deze zich voordoet als uit den doode teruggekeerd. Deze episode moge hier nog volgen.

De uispraak van het Sawun. kan voldoende blijken uit de Woordenlijst van I. K. Wijngaarden. Verbinding van het pers. voornw. met het verbale woord is in het Sawun. onbekend; vervoeging der verba in de interlineaire vertaling geschiedt dus alleen voor de kortheid.

$$
\begin{aligned}
& \text { Bale-ri(1) ane (2) dou-au(3) ne:(4) "ki- ḍo oö ou ta(5)-kako, } \\
& \text { w. vorst als niet wilt gij gaan }
\end{aligned}
$$

ne (6) li-(7) pepú- ja naḍé, nè-ri hehi: la-(8) pengĕdu bevelen mijn dit is weer een breng

woperĕgu (9) wie ĕpu-(10)di do menata!" (11) Bale ane gebak geven v. ons die onderw. w. 
Pepeka : "òö ma-ke (12) ja ta-kako, tao we (13) mu wil $\mathrm{ik}$ gaan makt gijl. woperĕgu, miḍje ta-kako ja mĕḍa ḍe," ane Pepeka ne gebak dat ga ik avond deze w.

li (14) pa dou-ae ne. Ta-ware-ke Pepeka la (ӗ)mu-(15)no, z. aan vorst keert naar huis zijn ḍje (16) li ta-la-wěli lai-ludu are-laka, ḍje li ta-kĕḍji

$$
\text { z. koopen bĕras kêtan } \quad \text { z. stampen }
$$

ta-kebĕte, ta-ĕla-le (17) hari-hari pekĕḍji,(17) ta-kehihi-ke ri tot-meel af stampen zeven door dupămu-(18)no, ḍje lilo (lilu) (19) nga donahu, ḍje wòre vrouw zijn meedt suiker rolt

(wòro) pemòneae, (20) dije tao mi dou- he,(21) do era lang maken als mensch die is

nga ruai nga rubebo, pehelaü (20) nga medera Pepeka met arm met been gelijk met hoog(te)

hari nga worěwu Pepeka. Ta-ěla-le pe-tao(17) hari-hari, samen met gelaat af maken alles ḍje ròhe (ròho) ri ĕru mĕdi, dje pepue (pepú) ne dou wrijft met pot zwart zendt mensch Pekeka la-pika pa dou-ae ne, ta-la-ridju- ke Pepeka. Bale melden aan vorst springen

ane dou-ae ne: bole dae, mĕḍa bĕlirai ngara-ko, (22) w. vorst djangan nog avond morgen eerst

d̦je ridju. Ta-langu-ke dou dou-ae ne la-ĕta aḍju adu, dan springt roept mensch vorst kappen hout hart

d̦je tunu pe-lawá, (23) ḍje hali la roä, do ta-ridju Pebranden kool indoen in kuil die te-springen

peka ne. Ta-moko-le ne lawá-ai- he, ta-marango- ke ne rai klaar kool vuur onduidelijk aarde ne, d̦je la-pedoe (pedoa) Pepeka ta-la-ridju la roä ne, nga roepen springen in kuil met ĕgu li-moa dou-ae ne, wie do menata. Ta-pemoko- ke dragen zenden vorst geven die onderw. maakt-klaar

ĕni Pepeka, dje la-pewuni ěni la dĕmu, d̦je peridjo (peridju) zich verbergt zich op zolder doen springen

ne nadou, do wòre ri dupămu Pepeka, ta-heroë (heroö)-ke pop die rollen door vrouw draagt

ne li-moa dou-ae-ne. Dje ridju la roä ne, dje heleo zenden vorst springt in kuil kijken 
ri dou do ae he. Bale ane dou-ae ne: "made tĕra-ke door mensch die veel w. vorst dood waar reeds. Pepeka, "toi d̦o ri no ta-kebĕte, ne tao ta-dou, weet niet door hem meel maken tot-mensch ta-hò (hou) ne ngiü Pepeka, ne tao dupămu-no, nge vervangen lijf maken vrouw zijn meent ta-Pepeka tĕra-ke ri dou-ae ne. Bale-ri ane dou-ae ne, ne waar door vorst w. vorst

li pa dou- no: "made-ke Pepeka, pemoko we di ĕni, z. aan mensch-zijn dood- reeds. maken-klaar wij (zich) rai-ḍjĕmi-ae ta-la-ĕgo (ĕgu) ne dupămu Pepeka ne, "ane vroeg halen vrouw w.

dou-ae ne. Ta-ḍai ta- terora mĕḍa, ta-puru-ke Pepeka ngĕti vorst komen tot midden nacht daalt van d̦ĕmu ne, djje la-djiu ei donahu, dje ròhe (ròho) ri awu zolder baadt water suiker wrijft met asch

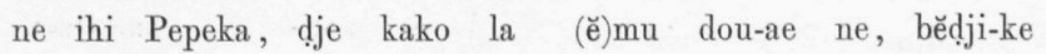
lijf gaat naar huis vorst slapen-reeds hari-hari ne dou pa (ё)mu dou-ae ne, ta-keděku-ke kelai allen mensch in huis vorst klopt deur Pepeka li ta-bòka. Ta-merei- ke dou-ae ne, ḍje la-bòka z. openen ontwaakt vorst opent uba- kelai pa Pepeka. Bale ane dou-ae ne: "nadú naḍép" (mond)-deur aan wie vorst deze

Bale ane Pepeka: "ja ma-ke, dĕka ti menata." Ta-kebĕdi-ke w. $\mathrm{ik}$ kom van ondw. schrikt

ne dĕniade dou-ae ne, d̦je la-pika pa dupămu-no: "tangá hart vorst zegt aan vrouw zijn hoe

ku do-ḍo (24) made Pepeka pa roä worai ne, do tòbo dat niet dood in kuil aarden die vol

ri lawá ai?" Ta-la-kerei-ri -ke pa Pepeka ri dou-ae ne: met kool vuur vraagt weer an door vorst

"minamí ne lai kako-ou, Pepeka, tangá ku melila ne hoe weg gaan uw hoe dat snel děka- ou, hĕku do-ḍo rĕdja ou ?" ane dou-ae ne. Bale-ri komst uw, dat niet lang gij w. vorst

ane Pepeka: "nè ne li-moa do menata pa ja wie w. is zenden die ondw. aan mij geven dou-ae", ane Pepeka, "li ta-pedoe (pedoa) dou-ae li ta-kako-le, vorst w. z. roepen vorst z. gaan-ook 
ane, ne pepue (pepú) ja ma-(8) pika pa dou-ae." "Bole-ako(25) w. bevelen mij zeggen aan vorst misschien

ou ta-uku," ane dou-ae. Bale ane Pepeka: "tĕra minahăre, gij liegen w. vorst - w. waar aldus

kiri děka di la menata, ta-petabe-ke di, ḍje wòba worena als komen wij in onderw. begroeten ons schieten kanon ne do menata he." "Kako helaü di," ane dou-ae ne. die onderw. Gaan samen wij w. vorst

Bale ane Pepeka "kako ḍo- ke ja, dĕka ma-ke ja ngĕti w. ga niet meer ik, kom ik van

menata." "Kako ḍo ja miha, ridju uru ou, Pepeka", onderw. $\mathrm{Ga}$ met ik alleen, spring eerst gij

ane dou-ae ne. "Ie ḍ̀ minahăre, kiri ridju uru ja, w. vorst goed niet aldus als spring eerst ik ja-ke ne djaḍi ta-dou-ae," ane Pepeka. Ta-tu-ke dou-ae ik word tot-vorst w. geschiedt vorst

ne ta-ridju hari nga dou- no.

springen samen met mensch-zijn.

\section{AANTEEKENINGEN.}

1. Bale, "omgekeerd, om terug te keeren tot," is in beteekenis ongeveer gelijk geworden aan: "wat betreft" voor een voorop geplaatst substantief. Het wordt meermalen gevolgd door ri, wederom, wat in deze verbinding zonder beteekenis is geworden.

2. Ane, woord, het zeggen; meestal als absolutivum gebezigd.

3. Dou-ae, groot(e) mensch (man), titel van den vorst.

4. Ne na een subst. is het enkelvoudig lidwoord.

5. De functie van het zoo tallooze malen voorkomende ta is met weinig woorden moeilijk aan te duiden. Beknopt (zij het dan ook zeer onvolledig) gezegd, heeft het dikwijls geen anderen rol, als het voor een verbaal woord staat, dat naar onze opvatting een verbum finitum is, dan dat het dit verbum of praedicaat meer bepaaldelijk als zoodanig aanduidt; het kan dan ook altijd wegblijven, Voorst komt het nog voor zulke verba, welke wij beschouwen als deelwoorden of afhankelijke infinitieven, (waarbij behooren de praedicaten van onze onderwerps- en voorwerpszinnen); bijv. oö ja ta-kako, ik wil gaan; ta-li no ta-kako, hij beveelt te gaan; ie ta-kako ja, het is goed, dat ik ga; toi do ri ja ta-děka no, ik wist niet, dat hij kwam; (het Biman. zou in al deze zinnen een verbaal subst. 
bezigen). Hierbij behoort natuurlijk het gebruik van ta voor substantieven, als deze voor een geheelen zin staat, bijv. toi do ri no ta-keběte, hij wist niet, dat het meel was. In voorzinnen is ta soms door "nadat" weer te geven, bijv. beneden: ta-moko, nadat gereed was; ta-dai, nadat (het) gekomen was, enz.

Het is hier niet de plaats om over de verhouding van dit gebruik van ta tot het eerst genoemde te spreken; ook de andere functien kunnen hier voorbijgegaan worden.

6. Ne voor een subst. is in zekeren zin het tegenovergestelde van ta; het staat alleen voor subst., hetzij ze als subject, object of absolutivum voorkomen, en duidt deze (wederom kort en onvolledig gezegd) als zoodanig aan. Het duidelijkst blijkt dit bij woorden van verbale beteekenis: ta-dĕka ja, beteekent: ik kom, kwam, enz.; ne dĕka ja, (als absolutivum), bij mijne komst; ta-li ja, ik zeg, enz.; ne li ja, bij mijn zeggen, of naar mijn zeggen.

7. Li-pepú; met li , hier als subst., "geluid", "woord", wordt een soort van afgeleiden subst. gevormd; dus van pepú, bevelen, li-pepú, bevel; li-moa, (zie beneden) van moa, zenden : boodschap, maar ook: wat gezonden wordt, geschenk.

8. La voor een verbaal woord, duidt de richting, van den spreker af, aan; wij kunnen het dikwijls door "gaan" overzetten: ta-la-wĕli, hij gaat koopen.

Het omgekeerde is ma: ta-ma-wĕli, hij komt koopen.

9. Woperĕgu; wo is een verkorte vorm van het woord voor vrucht, (thans wue, M. P, wuah); het staat gewoonlijk voor de namen van vruchten, bijv. wo-pau, mangga-(vrucht). In woperĕgu is het onafscheidelijk aan het woord verbonden en is te verklaren, evenals in: wowadu, steen, enz. door den eenigzins ronden vorm. Worai, (zie beneden), is aarde als stof, aardkorrels, tegenover rai, aarde.

10. Е̌pu, grootvader, enz., v. d. voorouders.

11. Menata, de onderwereld; do menata, die in de onderwereld zijn, bewoners der onderwereld.

12. Ma-ke, doet, evenals ke, (reeds), dikwijls alleen dienst als nadrukwijzer.

13. We, slechts, maar, wordt dikmaals bij den imperatief gebezigd.

14. Li, zeggen, bevelen. 


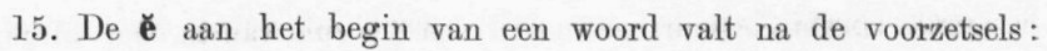
la, pa, ma, gewoonlijk weg.

16. Dje, toen, vervolgens.

17. Ta-ěla-le pe-kĕḍji. Het perfectum wordt gevormd met ĕla, (Mal. habis), terwijl het verbum pe, (hier oorspronkelijk de praepositie pa), voor zich krijgt.

Ta is hier door "nadat" (vgl. Aant. 5.) weer te geven; le, "ook", duidt het meervoud aan.

18. Dupămu, uit: don pa ĕmu, mensch in huis = echtgenoote.

19. Lilo (lilu), het woord tusschen haakjes duidt den eigenlijken vorm van het woord aan. De tweede wordt in het algemeen alleen gebruikt bij transitieve verba, als het object enkelvoudig en dus ook bepaald is.

20. Pemòneae, van mòneae, groot, lang; met pe worden zoowel causatieve werkwoorden (welke ook als bijwoord dienst doen), als reciproque gevormd; bijv. pehelaü, (vergel. beneden), van helaü, gelijk; zij zijn gelijk met elkander, ook: hij is gelijk met.

21. He, meervoudig lidwoord; bij vergelijkingen staat het subst. steeds in het meervoud.

22. Ngara-ko, eene samenkoppeling van twee woorden van dezelfde beteekenis.

23. Pelawá, van lawá, kool; dit gebruik van pe (samenhangend met het sub Aant. 16 genoemde), is alleen in enkele uitdrukkingen overgebleven.

24. Gewoonlijk geeft do voor do (evenals in het algemeen voor verbale woorden) een durativum te kennen; do-do kako no, kan bijv. beteekenen: hij pleegt niet te gaan; tegenover kako do , hij gaat niet; na ku, hĕku, evenwel is de beteekenis verloopen.

25. Bole ako schijnt eigenlijk te beduiden: gekscheer niet. De uitdrukking heeft echter, in gewoon gebruik, de beteekenis van ons "misschien."

\section{Vertaling.}

De vorst zeide: "als gij niet wilt gaan, op mijn bevel, dan heb ik nog een anderen last: ga gebak (van fijn gestampte maïs met suiker) brengen aan onze voorvaderen in de onderwereld." 
Pepeka sprak: "ik wil wel gaan; maak het gebak maar gereed, opdat ik van avond gaan kan"; zoo sprak hij tot den vorst.

Hij keerde naar zijn huis terug en beval ontbolsterde kleefrijst te gaan koopen; die rijst dan te stampen en als alles gestampt was, moest het door zijne vrouw gezeefd worden, waarna zij het kneedde met suiker tot eene langwerpige rol en gaf er den vorm van een mensch aan, met armen en beenen, in grootte en gestalte overeenkomende met Pepeka. Toen alles zoo ver klaar was, werd het ingewreven met zwartsel (roet) uit den pot; Pepeka zond zijn dienaar om den vorst mede te deelen, dat hij gereed was om naar beneden te springen.

De vorst sprak: "wacht nog een weinig, morgenavond eerst moet hij naar beneden springen."

De vorst riep nu volk op om hard hout te gaan kappen en dat tot kolen te verbranden, die in den kuil te doen, waarin Pepeka moest springen. Toen de kolen gloeiend waren, begon het land onduidelijk te worden (viel de avond); men ging Pepeka roepen om in den kuil te springen, medenemend al wat de vorst gezonden had voor hen, die in de onderwereld waren. Pepeka maakte zich gereed, maar verborg zich op zolder en liet de pop, welke zijn vrouw gemakt had, naar beneden springen, onder den arm dragend, al wat den vorst gezonden had. De menigte zag het, dat hij (schijnbaar) naar beneden sprong.

De vorst sprak: "nu is Pepeka werkelijk dood;" hij wist niet, dat het maar meel was, waaraan een menschelijke vorm gegeven was ter vervanging van Pepeka, door diens vrouw gemaakt; hij meende, dat het werkelijk Pepeka was.

De vorst sprak daarna tot zijne lieden:

"Pepeka is dood; laten wij ons gereedmaken om morgen vroeg zijne vrouw te gaan halen;“ zoo sprak de vorst.

Toen het middernacht geworden was, daalde Pepeka van den zolder af, baadde zich in suikerwater en wreef zich in met asch; daarop ging hij naar het huis van den vorst, waar allen in het huis reeds sliepen, Pepeka klopte op de deur en verzocht open gedaan te worden. De vorst ontwakte en deed de deur voor hem open. De vorst sprak: "wie is daar?"

Pepeka zeide: "ik; ik kom uit de onderwereld."

De vorst verschrok en ging heen en zeide tot zijne echtgenoote: "hoe is het toch mogelijk, dat Pepeka niet omgekomen is in den kuil in den grond vol gloeiende koleu! “ Hij ging daarop naar 
Pepeka en vroeg hem: "hoe zijt gij gevaren, Pepeka; hoe komt het, dat gij zoo spoedig terugkeert, dat gij niet langer uitblijft?" zoo sprak de vorst.

Pepeka zeide: "ik heb eene boodschap voor u van hen, die in de onderwereld zijn," sprak hij, "om u te bevelen snel daarheen te gaan, dat hebben zij gezegd, mij zendende om het u te gaan mededeelen."

"Misschien liegt gij wel," zeide de vorst.

Pepeka sprak: "het is werkelijk zoo; als wij in de onderwereld komen, dan begroeten ons de voorvaderen en schieten kanonnen af." "Laat ons samengaan", zeide de vorst.

Pepeka sprak: "ik ga niet weer, ik kom pas uit de onderwereld." "Ik ga niet alleen, spring gij eerst naar beneden, Pepeka", zeide de vorst.

"Dat kan niet, als ik 't eerst sprong, zou ik (daar) vorst worden," zeide Pepeka.

Toen geschiedde het, dat de vorst met zijne lieden naar beneden sprong.

Ten slotte kan ik nog mededeelen, dat het Toradjasche verhaal omtrent Laï, (t. a. p. pag. 126 vlg.), die zijn vader wijsmaakt, dat zijne moeder gestorven is, en omgekeerd zijne moeder doet gelooven, dat zijn vader gestorven is, en ze daarna beiden weder met elkander doet huwen, mij ook bekend is in het Sumbawareesch, Kupangsch en Sumbasch. De verhalen zijn evenwel te lang om hier in te lasschen.

Amsterdam, September 1903. 